\title{
Comparison of Changes in Soil Moisture Content Following Rainfall in Different Subtropical Plantations of the Yangtze River Delta Region
}

\author{
Xin Liu ${ }^{1}$, Yingzhou Tang ${ }^{1,+}{ }^{\text {, Xuefei Cheng }}{ }^{1}$, Zhaohui Jia ${ }^{1}$, Chong Li ${ }^{1}$, Shilin $\mathrm{Ma}^{1}$, Lu Zhai ${ }^{2}$, Bo Zhang ${ }^{2}$ \\ and Jinchi Zhang ${ }^{1, *}$ \\ 1 Co-Innovation Center for Sustainable Forestry in Southern China, Jiangsu Province Key Laboratory of Soil \\ and Water Conservation and Ecological Restoration, Nanjing Forestry University, 159 Longpan Road, \\ Nanjing 210037, China; liuxinswc@njfu.edu.cn (X.L.); tangyingzhou@njfu.edu.cn (Y.T.); \\ xuef1127@163.com (X.C.); zhjia2018@163.com (Z.J.); cli5104@njfu.edu.cn (C.L.); supermsl@163.com (S.M.) \\ 2 Department of Natural Resource Ecology and Management, Oklahoma State University, \\ Stillwater, OK 74078, USA; zhailu@bio.miami.edu (L.Z.); bozhang@okstate.edu (B.Z.) \\ * Correspondence: zhang8811@njfu.edu.cn \\ $+\quad$ These authors contributed equally to this work.
}

check for

updates

Citation: Liu, X.; Tang, Y.; Cheng, X.; Jia, Z.; Li, C.; Ma, S.; Zhai, L.; Zhang, B.; Zhang, J. Comparison of Changes in Soil Moisture Content Following Rainfall in Different Subtropical Plantations of the Yangtze River Delta Region. Water 2021, 13, 914. https:// doi.org/10.3390/w13070914

Academic Editor: José María Senciales-González

Received: 23 February 2021

Accepted: 25 March 2021

Published: 27 March 2021

Publisher's Note: MDPI stays neutral with regard to jurisdictional claims in published maps and institutional affiliations.

Copyright: (c) 2021 by the authors. Licensee MDPI, Basel, Switzerland. This article is an open access article distributed under the terms and conditions of the Creative Commons Attribution (CC BY) license (https:// creativecommons.org/licenses/by/ $4.0 /)$.
Abstract: Rainfall is an indispensable link in the atmospheric water cycle, which plays a critical role in forest hydrology. Quercus acutissima and Cunninghamia lanceolata are two fast-growing and economically important tree species in the middle and lower reaches of the Yangtze River. They are extensively applied in the restoration of vegetation, hydraulic engineering, and the development of artificial forests. The primary aims of this study were to describe and compare the changes in soil water content following rainfall events, while elucidating their relationships to environmental factors. From September 2012 to August 2013, we monitored the soil moisture at different depths every $30 \mathrm{~min}$ using commercially available soil moisture measuring devices. Hourly meteorological data were monitored over an open area at $200 \mathrm{~m}$ from the sample site, including photosynthetically active radiation $\left(\mathrm{P}_{\mathrm{ar}}\right)$, air temperature $\left(\mathrm{T}_{\mathrm{a}}\right)$, relative air humidity $(\mathrm{RH})$, vapor pressure deficits $\left(\mathrm{V}_{\mathrm{pd}}\right)$, rainfall, and wind speed. The results revealed that variations in the soil moisture content during summer $\left(C_{v}=0.231\right)$ and autumn $\left(C_{v}=0.0 .170\right)$ were greater than during spring $\left(C_{v}=0.0 .092\right)$ and winter $\left(C_{v}=0.0 .055\right)$, with those in the deep soil moisture $\left(C_{v}=0.117\right)$ being smaller. The soil moisture content was significantly altered following the cessation of rainfall, where the initial and average moisture content, and the ACR of the soil increased with higher rainfall intensities. The ACR was positively correlated with $\mathrm{T}_{\mathrm{a}}(\gamma=0.16), \mathrm{RH}(\gamma=0.46)$ and rainfall $(\gamma=0.22)$, but negatively correlated with $\mathrm{P}_{\mathrm{ar}}(\gamma=-0.29), \mathrm{V}_{\mathrm{pd}}(\gamma=-0.23)$, and wind speed $(\gamma=-0.01)$. This study provides valuable information regarding the hydrological processes of artificial forests in the middle and lower reaches of the Yangtze River.

Keywords: rainfall; soil moisture content; environmental factors; ACR of soil moisture content; Yangtze River Delta region; Tong Shan forest farm

\section{Introduction}

According to the results of the Ninth National Forest Resources Inventory, the area of artificial forest in China has reached $79,542,800 \mathrm{hm}^{2}$, which accounts for $32.94 \%$ (almost a third) of its total forested area [1]. Plantations play critical roles in the greening of the land and improvement of ecosystems. An in-depth study of hydrology can have a profound impact on the sustainable development of plantations, encompassing their formation and the regulation of water distribution. The quantity and intensity of rainfall directly influence the soil moisture of artificial forests, which is an important comprehensive index of water circulation in terrestrial ecosystems [2,3]. Soil moisture encompasses ambient atmospheric water vapor, groundwater, surface water, and biological water [4], each of which play 
critical roles in the hydrological circulatory system. Soil water is a comprehensive indicator of the status of climate, vegetation [5], topography [6,7], and land use patterns [8,9]. It is an essential parameter that impacts the growth and development of vegetation, as well as a key factor that affects the succession of vegetation in ecosystems. The attributes of precipitation, including rainfall amounts and frequency, affect the behavior of soil moisture $[10,11]$. Therefore, an investigation into the responses of soil moisture to rainfall events is of particular importance as it relates to soil water resources, which has practical significance for the rational use of regional water resources.

Soil moisture content reflects localized hydrological characteristics, where there can be significant variations in areas with different types of vegetation cover. A greater soil moisture content indicates that local rainfall is higher, or that the soil water retention capacity is stronger [12], otherwise the soil moisture content is lower, and soil erosion is reduced due to plant cover [13]. Soil moisture possesses both spatial and temporal variability. Previous studies found that the spatial variability of soil moisture increased with regional changes [14], and the coefficient of variation of soil moisture decreased with higher average soil moisture [15]. Vegetation cover can effectively reduce soil moisture variability following rainfall $[16,17]$, which is also seasonally affected $[18,19]$. Soil moisture is the critical link that connects all aspects of the hydrological cycle, and since it is essential for the growth and coverage of vegetation, it is a good indicator of a healthy environment. Soil moisture can also directly reflect the amount of underground runoff. Good vegetation growth and adequate transpiration can effectively supplement atmospheric moisture and provide the necessary conditions for rainfall, which can supplement surface runoff and soil moisture over time; thus forming the complete hydrological cycle [20].

Numerous previous studies have revealed that soil moisture content is severely impacted by land use patterns [21] and environmental factors, including topography [22,23], rainfall intensity [24], soil temperature, solar radiation, vapor pressure differences, $\mathrm{T}_{\mathrm{a}}$ [25], and more [26]. Other research has shown that southern slopes receive more solar radiation than northern slopes; thus, the soil temperature is higher, and the soil moisture is lower [27-30]. In general, the higher the slope, the lower the soil water content [29-31]. The soil water content of concave slopes are generally higher than that of convex slopes, which is due to a significant correlation between the slope shape and its soil drainage capacity [32]. In comparative tests involving various land-use models, it was revealed that the soil moisture content of bare land was always highest [33], whereas the soil moisture content of grassland was significantly higher than that of camphor pine [34]. The water-holding capacity of pine forests was lower than that of cultivated land, grasslands, and shrub areas. In most cases, the soil moisture content of shrubs and grasslands was at medium and high levels over short periods [35], which may have been caused by the enhanced hydrophobicity of pine trees [36].

Research into the effects of environmental factors (e.g., $\mathrm{P}_{\mathrm{ar}}$ and $\mathrm{T}_{\mathrm{a}}$ ) on soil moisture, signified that the change in $\mathrm{P}_{\text {ar }}$ was negatively correlated with that in the average soil moisture content. This was because sun exposure was the direct cause of evaporation from the shallow surface soil. The effects of precipitation and sunlight on soil moisture dynamics were greater than that of soil temperature [37]. The average soil water content was inversely proportional to both air and soil temperature, where the soil water content decreased with higher temperatures [38,39]. Rainfall intensity has the most direct impact on soil water content compared to multiple other environmental factors. It is generally believed that the greater the intensity of rainfall, the higher the soil moisture content [40]; however, this was found not to be the case in other studies. Firstly, this phenomenon was observed to occur only under the condition of moderate humidity, where the increased soil water content corresponded with cumulative rainfall [41]. Secondly, changes in the soil water content demonstrated exponential curve fitting. With greater rainfall intensity, the divergence near the best fitting line increased, which may have been caused by the ability of heavy rainfall to destroy near-surface soil structures [42]. Furthermore, the relationship between rainfall intensity and infiltration depth was linear [43]. 
Studies have indicated that precipitation of less than $5 \mathrm{~mm}$ cannot supplement the soil water content; however, it can be enhanced with precipitation of between $5 \mathrm{~mm}$ and $20 \mathrm{~mm}$. Precipitation levels at $>20 \mathrm{~mm}$, from 0 to $40 \mathrm{~cm}$ [44], and from 0 to $100 \mathrm{~cm}$ can significantly increase the soil water content. Furthermore, the precipitation intensity significantly affected the infiltration rate, where the higher the intensity, the deeper and faster the infiltration [45]. When there was a prolonged interval between two precipitation events, the soil water content of each soil layer decreased continuously over time. Meanwhile, the water content at the 0 to $40 \mathrm{~cm}$ soil depth was significantly affected by precipitation and wind speed [41], whereas at the 0 to $100 \mathrm{~cm}$ soil depth it was strongly influenced by the relative humidity and water pressure.

Although a plethora of studies have explored the relationships between rainfall and soil moisture, these studies typically focused only on changes in soil moisture after the beginning of rainfall. However, it is still not clear how the soil water content is altered over time following different rainfall intensities, and what the key factors are that determine these changes. Based on the water distribution characteristics of the main afforested tree species in the middle and lower extents of the Yangtze River, this investigation employed long-term position monitoring equipment to continuously monitor the study area. This strategy provided more coherent and sufficient monitoring data, while establishing a solid foundation for the future study of plantation hydrology.

To explore the influences of different rainfall events on soil moisture, we conducted a series of observational experiments in a typical plantation system in the Yangtze River Delta region. Our main objectives were to: (1) compare changes in the soil moisture content of various soil layers during different seasons in the study area; (2) analyze the influences of initial and average precipitation loads on the overall soil moisture content following rainfall events; (3) verify the relationships between changes in the soil water content and environmental factors.

\section{Materials and Methods}

\subsection{Study Site}

The study site (Figure 1) was located in Tongshan Branch, at the Dongshanqiao Forest Farm, in Nanjing, China $\left(31^{\circ} 35^{\prime} \sim 31^{\circ} 39^{\prime}\right.$ N, $118^{\circ} 50^{\prime} \sim 118^{\circ} 52^{\prime}$ E). The Tong Shan Forest Farm resides in a north subtropical monsoon zone, with a mild and humid climate, distinct seasons, and abundant water resources. The average annual temperature is $16.5^{\circ} \mathrm{C}$, with a maximum of $28.6^{\circ} \mathrm{C}$ in July and minimum of $3.1^{\circ} \mathrm{C}$ in January. The frost-free period lasts 229 days, and the annual sunlight amounts to $2199.5 \mathrm{~h}$. The water resources are abundant with an annual average precipitation of $1126.9 \mathrm{~mm}$, with a rainy season that spans from June to August with an average rainfall of $587.6 \mathrm{~mm}$ (Figure A1).
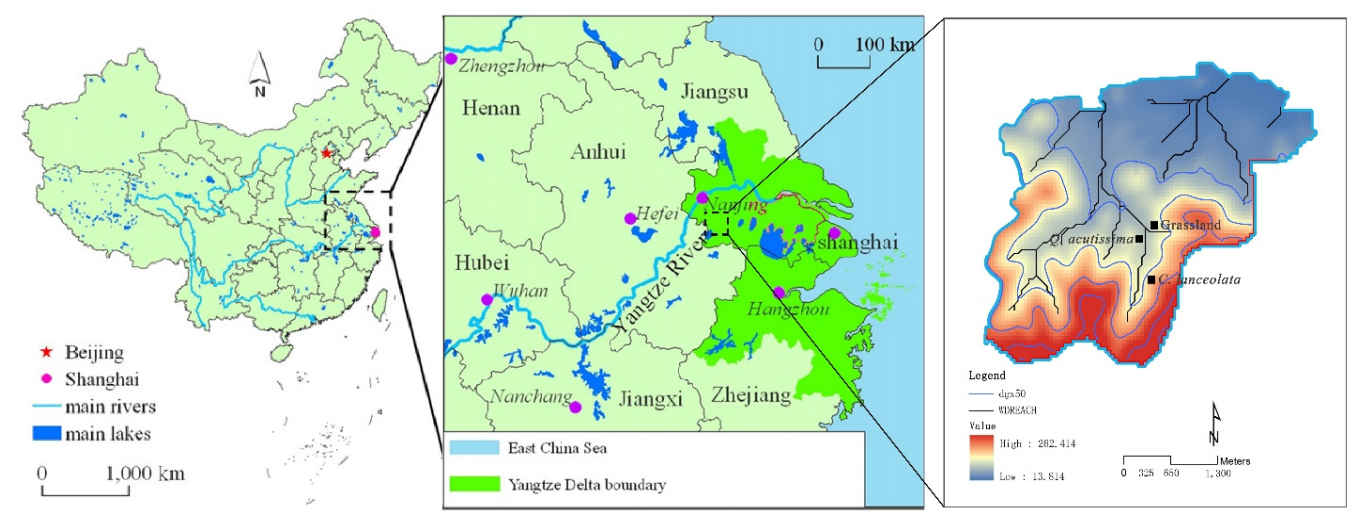

Figure 1. Study regional location and elevation map.

The soil type was yellow brown and the slope direction was northeast (NE). The soil thickness was $\sim 60 \mathrm{~cm}$, beyond which was weathered parent sandstone. The terrain comprised the southern Jiangsu hills at an altitude of from between 38-388 m, and the 
water table was at $<10 \mathrm{~m}$. The forest stand types included Q. acutissima, C. lanceolata, Phyllostachy, Pinus massoniana, and Camellia sinensis. The understory shrub herbs were primarily Lindera glauca (sieb.et Zucc.) BI, Rhus chinensis, Erigeron annuus, Arthraxon hispidus (Thunb.) Makino, and Rubus tephrodes Hance.

At the study site, a 45-year-old holm $Q$. acutissima forest was selected, with a canopy density of 0.8 (425 trees $/ \mathrm{hM}^{2}$ ) and an average tree height of $16.8 \mathrm{~m}$. The average DBH was $24.3 \mathrm{~cm}$ and the average crown width was $9.7 \mathrm{~m}$, with a forest floor slope of $18^{\circ}$ and a slope length of $62 \mathrm{~m}$. A 45-year-old holm lanceolata, Phyllostachy edulis forest was also selected with a canopy density of $0.61\left(850\right.$ trees $\left./ \mathrm{hM}^{2}\right)$, average tree height of $23 \mathrm{~m}$, average DBH of $22 \mathrm{~cm}$, average crown width of $13.6 \mathrm{~m}$, and a forest floor slope of $20^{\circ}$.

\subsection{Soil Moisture Measurements}

ECH2O probes (Decagon Devices Inc., Pullman, WA, USA) are soil moisture sensors that measure the single-value polynomial relationship between the soil moisture content and soil dielectric constant to calculate the moisture content of a soil volume [46]. The study site (slope $21^{\circ}$ ) was not affected by a forest margin, and a forest window was selected for fixed-point observations at four soil layers $(5 \mathrm{~cm}, 10 \mathrm{~cm}, 15 \mathrm{~cm}$, and $40 \mathrm{~cm})$. There was no distribution of roots with diameters greater than $0.5 \mathrm{~cm}$ within $10 \mathrm{~cm}$ of the soil water probe. Data were collected every $30 \mathrm{~min}$, and a set of repeated observation points were established at $3 \mathrm{~m}$ from the study site under similar lighting conditions. The mean data value was taken as the final soil moisture content value of a given soil layer. The observation duration extended from September 2012 to August 2013.

\subsection{Rainfall Measurements}

In an open field $200 \mathrm{~m}$ from the stand under study, a point with little influence on the forest margin and canopy was selected. Using a HOBO Counter (Onset Computer Inc., Bourne, MA, USA) the real-time rain cylinder monitoring of rainfall and its duration was conducted. Following each rainfall event any deciduous branches on the rain gauge were removed. According to the accumulated precipitation between two rainfall events, the rainfall amounts were divided into six levels, which were $\leq 2 \mathrm{~mm}, 2-10 \mathrm{~mm}, 10-15 \mathrm{~mm}$, 15-20 $\mathrm{mm}, 20-50 \mathrm{~mm}$, and $>50 \mathrm{~mm}$, respectively.

\subsection{Meteorological Measurements}

Additional meteorological factors, including photosynthetically active radiation $\left(\mathrm{P}_{\mathrm{ar}}\right)$, air temperature $\left(\mathrm{T}_{\mathrm{a}}\right)$, relative air humidity $(\mathrm{RH})$, soil temperature, and wind speed were measured via a CNR4 Net Radiometer (Campbell Scientific Inc., North Logan, UT, USA), HMP155A Temperature and Relative Humidity Probe (Campbell Scientific Inc., North Logan, UT, USA), HFP01 Soil Heat Flux Plate (Campbell Scientific Inc., North Logan, UT, USA), and MetOne 010C Wind Speed Sensor (Campbell Scientific Inc., North Logan, UT, USA), respectively. The vapor pressure deficits $\left(\mathrm{V}_{\mathrm{pd}}\right)$ were calculated by $\mathrm{T}_{\mathrm{a}}$ and $\mathrm{RH}$ data. All data were collected using an EM50 Data Logger (Decagon Devices, Pullman, WA, USA) [37,47].

\subsection{Soil Moisture Content Change Rate}

The soil moisture content change rate was calculated via linear regression according to the differences in the soil moisture content between two rainfall events:

$$
\mathrm{R}=\left(\mathrm{S}_{\mathrm{wct}}-\mathrm{S}_{\mathrm{wc}}\right) / \mathrm{t}
$$

where $\mathrm{R}$ is the change rate of the soil moisture content $\left(\% 0.5 \mathrm{~h}^{-1}\right), \mathrm{S}_{\mathrm{wct}}$ is the soil moisture content at the onset of a subsequent rainfall event (\%), $\mathrm{S}_{\mathrm{wc}}$ is the soil moisture content at the conclusion of the previous rainfall event $(\%), t$ is the interval between the end of a previous rainfall and the onset of a subsequent rainfall (per $30 \mathrm{~min}$ ). 


\subsection{Statistical Analyses}

The average value of the soil water content was calculated using a classical statistical method to analyze the concentration of soil water within the study scope. The spatial and temporal distribution and variability of the soil water content were articulated by calculating the standard deviation and coefficient of variation. The coefficient of variation $[14,48]$ reflects the relative variation, that is, the degree of dispersion of the random variable:

$$
C_{v}=\frac{\sigma}{\mu}
$$

In the formula, $\sigma$ is the standard deviation of the sample, and $\mu$ is the sample mean of the soil layer. According to the coefficient of variation [49], changes in the soil water content may be classified as weak $\left(C_{v} \leq 0.1\right)$, moderate $\left(0.1<C_{v}<1\right)$, and strong $\left(C_{v} \geq 1\right)$.

A Duncan test [50] was employed when one-way analysis of variance (ANOVA, SPSS Inc., Chicago, IL, USA) showed that meteorological factors had a significant impact on the rate of change of the soil moisture content of grassland, Q. acutissima, and C. lanceolata forests. To elucidate whether the mean between multiple samples was significant, two-way ANOVA was used to test the main effects and interactions of rainfall intensity, soil layer, initial moisture content, and average moisture content using SPSS 25.0. (IBM Inc., NY, USA) This, when correlation analysis revealed that meteorological factors were significantly associated with the soil moisture content, soil temperature, and the soil moisture content change rate. Redundancy discriminant analysis (RDA) was performed to reveal the relationships between the soil moisture content rate of change, soil temperature, soil moisture content, and environmental factors using Canoco 5.0 software (Microcomputer Power, Ithaca, NY, USA). The visualization of the data was achieved using OriginPro 8.5 software (OriginLab Inc., Northampton, MA, USA).

\section{Results}

\subsection{Rainfall}

The water content increased following rainfall events and began to drop once the rainfall stopped. A maximum daily rainfall of $76.2 \mathrm{~mm}$ was recorded on 7 June 2013, and the highest intensity was $14.2 \mathrm{~mm} / 30 \mathrm{~min}$ on 23 June 2013. The peak water content value appeared in June and July, while the valley value appeared in August (Figure 2). During the data collection period there were 114 rainy days, and the cumulative rainfall over 12 months was $798.4 \mathrm{~mm}$, with the rainfall distribution shown in Table 1. Minimal rain events $(\leq 2 \mathrm{~mm}$ ) were the most frequent and had the lowest contribution to the total rainfall. Intermediate rain events $(2-10 \mathrm{~mm})$ were the second most frequent, albeit they had the greatest contribution to overall rainfall. Heavy rain events ( $>50 \mathrm{~mm})$ were the least frequent but had the second greatest contribution to the total rainfall (Figure A2.).

\subsection{Soil Moisture Content}

Season, soil layer, and land type significantly influenced the soil moisture content $(p<0.001)$ (Figure 3). The impacts of season and soil layer interactivity were also significant, except for the effects of $C$. lanceolata. During the spring and summer, the moisture content of the $5 \mathrm{~cm}$ soil layer in the grassland and Q. acutissima forest was significantly higher than that of other soil layers $(p<0.05)$. Furthermore, with soil layer depth, the soil moisture content decreased significantly $(p<0.05)$, except for the $Q$. acutissima forest in summer.

During autumn and winter, the soil water content of the grassland and Q. acutissima forest initially increased and then decreased within the deeper soil layers, where the water content of the $15 \mathrm{~cm}$ soil layer was significantly higher than that of the other soil layers $(p<0.05)$. The soil water content of the $5 \mathrm{~cm}$ soil layer in the $C$. lanceolata. forest was significantly lower than that of the other soil layers $(p<0.05)$. Within the deeper soil layers, the soil water content initially increased and then decreased, where that of the $15 \mathrm{~cm}$ soil layer was significantly higher than for the other soil layers $(p<0.05)$. The soil moisture content during summer and autumn varied medially, whereas it was weakly variable 
during winter. During the spring, the soil moisture content in the $5 \mathrm{~cm}$ soil layer exhibited moderate variability, whereas it varied weakly in the $15 \mathrm{~cm}$ and $40 \mathrm{~cm}$ soil layers.
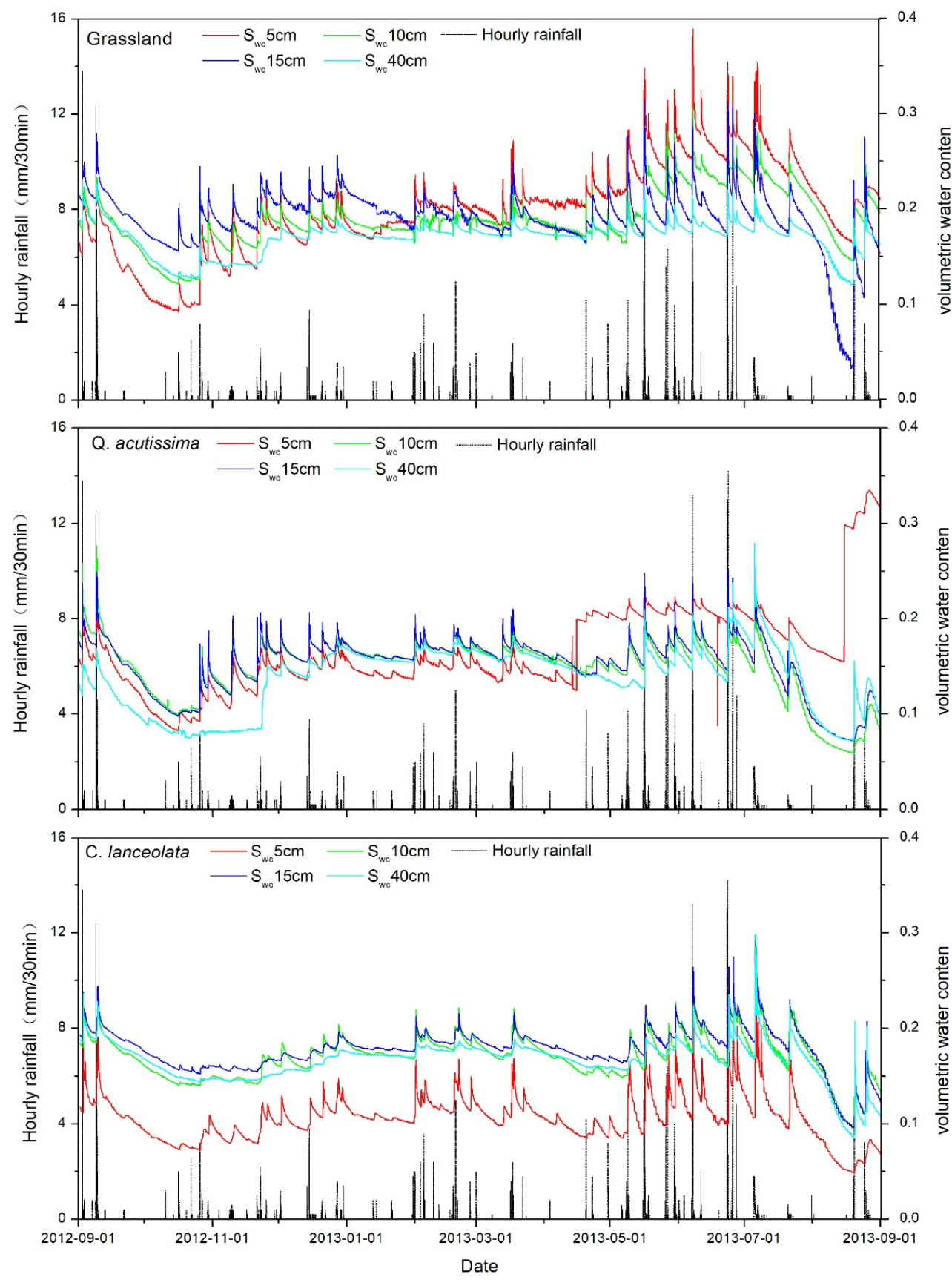

Figure 2. Seasonal course of relationship between soil moisture content and rainfall in grassland, Q. acutissima, and C. lanceolata between 9 September 2012 and 8 August 2013.

Table 1. Distribution of rainfall during study period.

\begin{tabular}{ccc}
\hline Rainfall & The Percentage of Amounts & The Percentage of Events \\
\hline$\leq 2 \mathrm{~mm}$ & $5.46 \%$ & $42.98 \%$ \\
$2-10 \mathrm{~mm}$ & $30.69 \%$ & $38.60 \%$ \\
$10-15 \mathrm{~mm}$ & $14.05 \%$ & $7.89 \%$ \\
$15-20 \mathrm{~mm}$ & $0.57 \%$ & $4.39 \%$ \\
$20-50 \mathrm{~mm}$ & $14.93 \%$ & $3.51 \%$ \\
$>50 \mathrm{~mm}$ & $24.30 \%$ & $2.63 \%$ \\
\hline
\end{tabular}



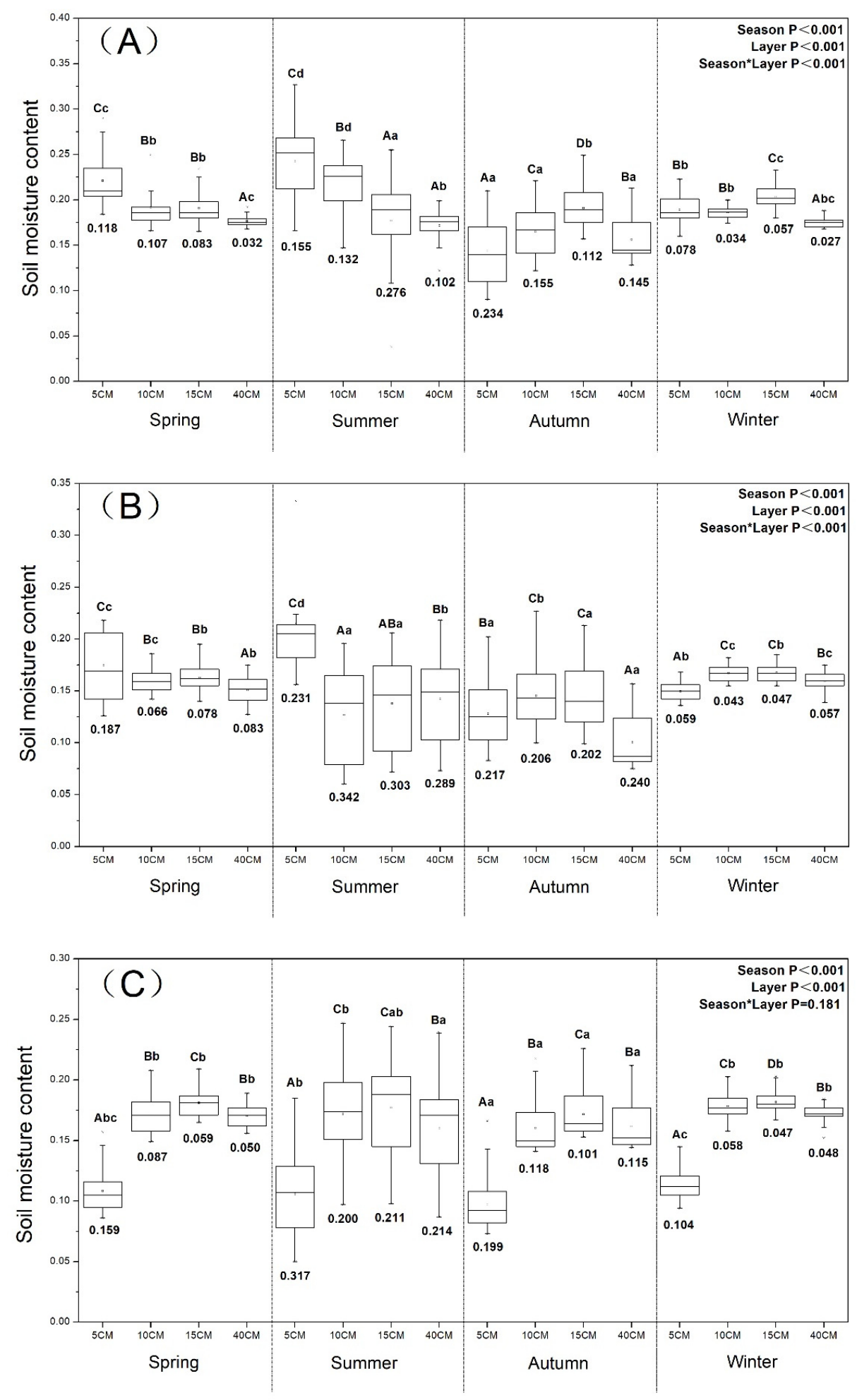

Figure 3. Box diagram of moisture content of each soil layer across four seasons (Note: Empty circles within each box represent the average soil moisture content value; middle lines within each box represent the median soil moisture content value; vertical lines represent the interquartile ranges; upper case letters indicate significant differences between different soil layers during the same season $(p<0.05)$; lower case letters indicate significant differences between different seasons of the same soil layer $(p<0.05)$; values below box charts are the coefficients of variation; $(\mathbf{A})$ : grassland; (B): Q. acutissima ; (C): C. lanceolata; land types: $p<0.001)$. 


\subsection{Environmental Factors Following Rainfall Events}

Among the six major environmental factors, there were no significant differences in wind speed $(p>0.05)$ (Figure $4 \mathrm{E})$, where $\mathrm{P}_{\mathrm{ar}}$ with a $15-20 \mathrm{~mm}$ rainfall intensity was significantly lower than $P_{a r}$ with a rainfall intensity $\leq 2 \mathrm{~mm}, 2-10 \mathrm{~mm}$, and 10-15 mm $(p<0.05)$ (Figure $4 \mathrm{~A})$. The $\mathrm{T}_{\mathrm{a}}$ with a $>50 \mathrm{~mm}$ rainfall intensity was significantly higher than $\mathrm{T}_{\mathrm{a}}$ with other rainfall intensities $(p<0.05)$ (Figure $4 \mathrm{C}$ ). The RH under a strong rainfall intensity $(15-20 \mathrm{~mm},>50 \mathrm{~mm})$ was significantly higher than for the low rainfall intensity ( $\leq 2 \mathrm{~mm}, 2-10 \mathrm{~mm}, 10-15 \mathrm{~mm})(p<0.05)$ (Figure 4B), whereas the $\mathrm{V}_{\mathrm{pd}}$ under a strong rainfall intensity $(15-20 \mathrm{~mm},>50 \mathrm{~mm})$ was significantly lower than for the low rainfall intensity $(\leq 2 \mathrm{~mm})(p<0.05)$ (Figure $4 \mathrm{D})$.
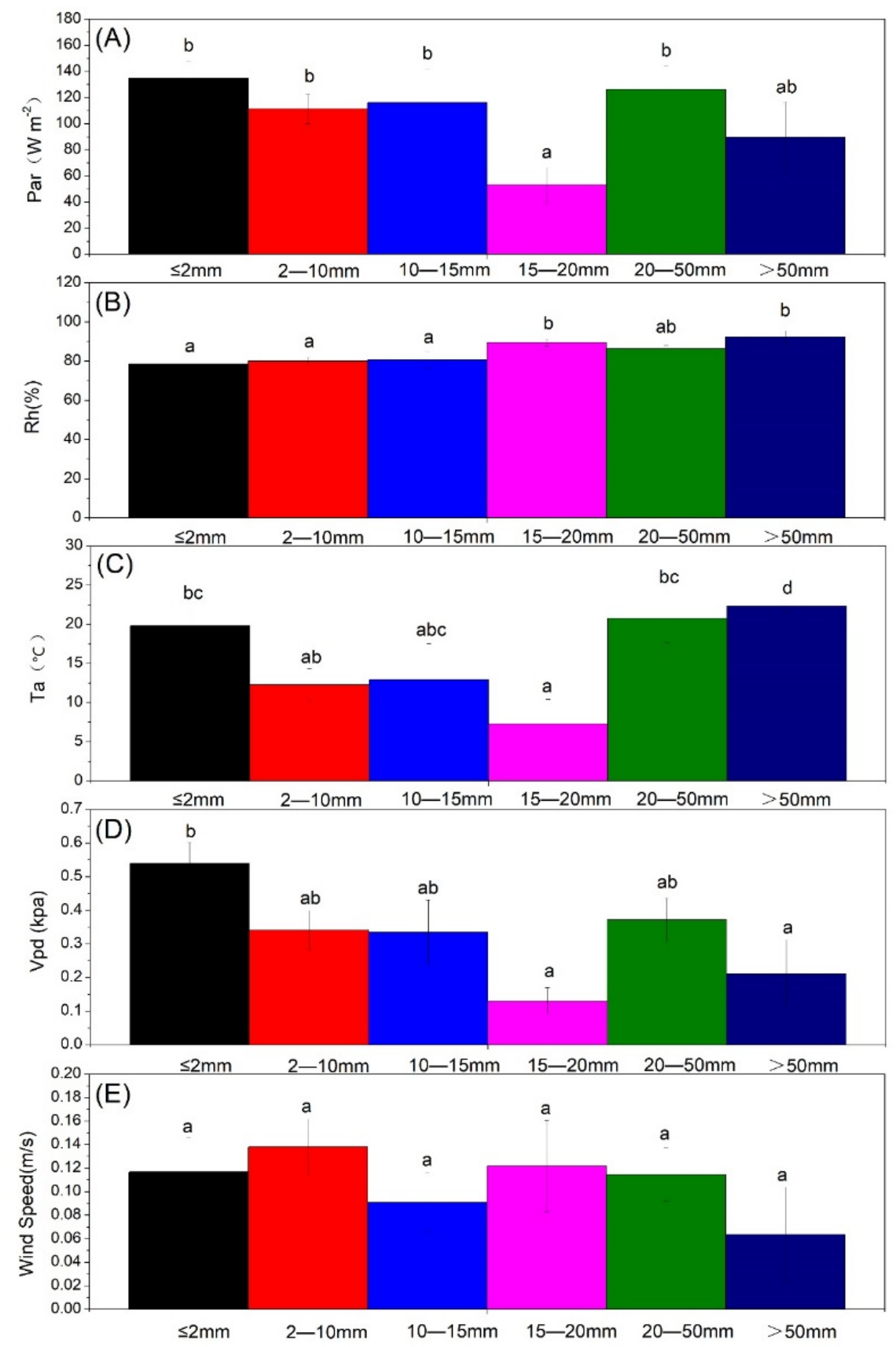

Figure 4. Environmental variables following different rainfall intensities. (Note: lower case letters indicate significant differences between different rainfall intensities $(p<0.05))$. 


\subsection{Soil Temperature and Moisture Content after Rainfall Events}

The rainfall intensity and land type significantly influenced the soil temperature $(p<0.001)$; however, the effects of rainfall intensity and soil layer interactions were not significant $(p>0.05)$ (Figure 5). The soil temperature with a rainfall intensity of 15-20 mm was significantly lower than that under a rainfall intensity of $>50 \mathrm{~mm}(p>0.05)$ (Figure 5). Following rainfall, the soil moisture content of the grassland, Q. acutissima, and C. lanceolata obviously changed. The moisture content increased with higher rainfall intensity; however, over time, the soil moisture content of each layer exhibited a downward trend (Figure 6).
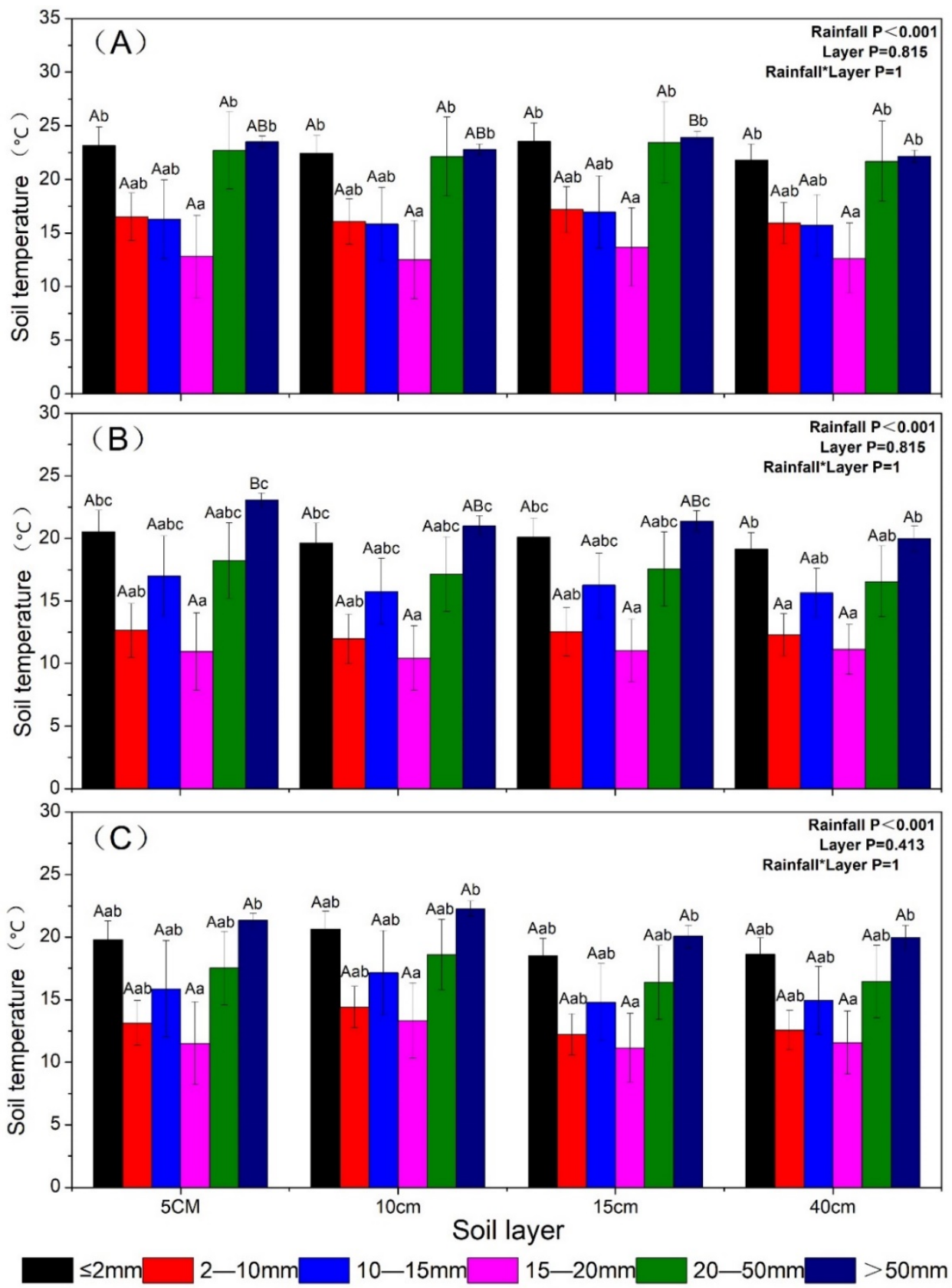

Figure 5. Soil temperatures in grassland, Q. acutissima, and C. lanceolata following different rainfall intensities. (Note: upper case letters indicate significant differences between different soil layers under the same rainfall intensities $(p<0.05)$; lower case letters indicate significant differences between different rainfall intensities within the same soil layer $(p<0.05)$; (A): grassland; (B): Q. acutissima ; (C): C. lanceolata; land types: $p<0.001)$. 

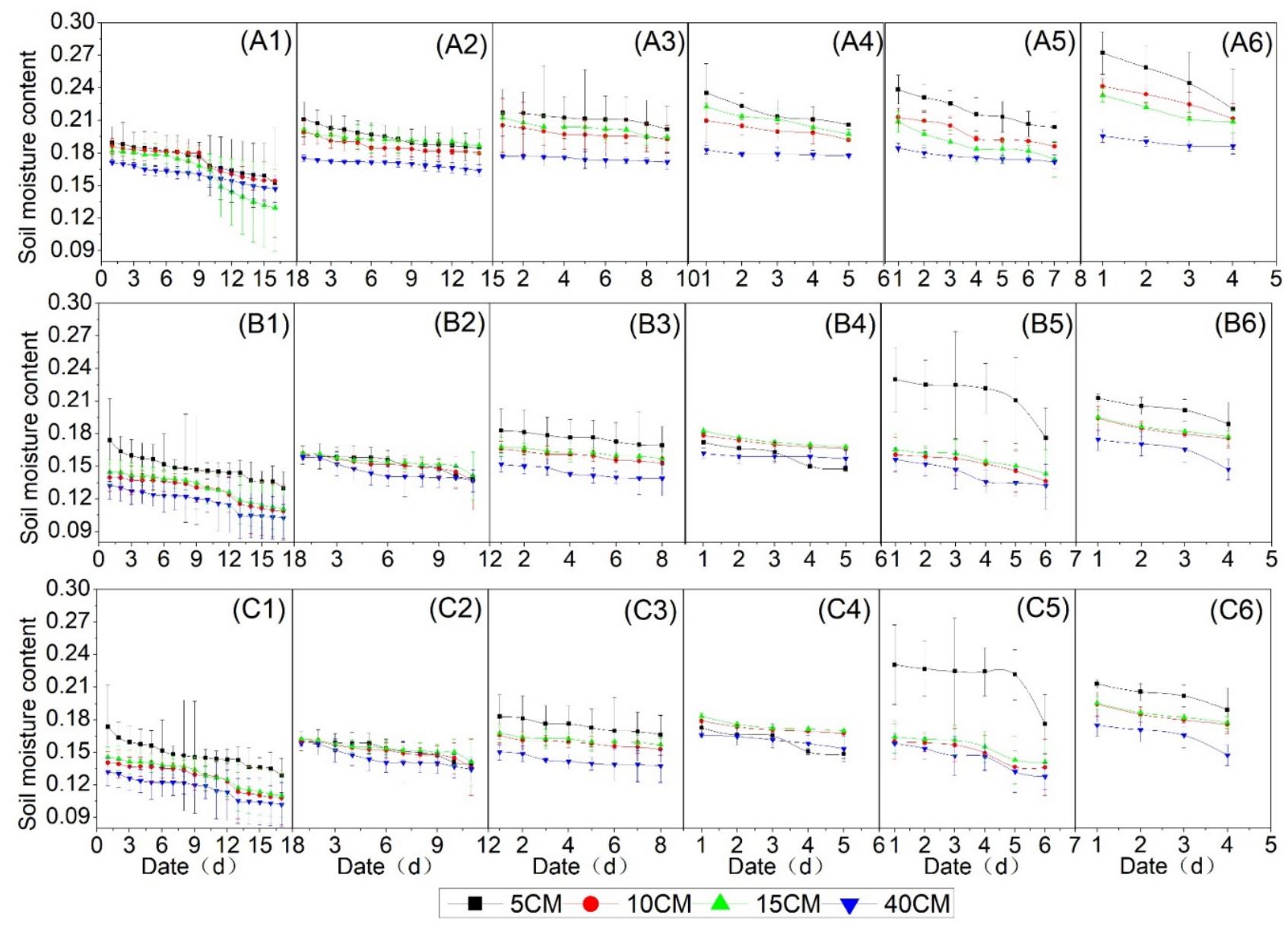

Figure 6. Variations in soil moisture content following different rainfall intensities. (Note: (A1-A6) are the variations in soil moisture content of grassland under rainfall intensities of $\leq 2 \mathrm{~mm}, 2-10 \mathrm{~mm}, 10-15 \mathrm{~mm}, 15-20 \mathrm{~mm}, 20-50 \mathrm{~mm}$, and >50 mm, respectively; (B1-B6) are the variations in soil moisture content in the Q. acutissima forest under rainfall intensities of $\leq 2 \mathrm{~mm}, 2-10 \mathrm{~mm}, 10-15 \mathrm{~mm}, 15-20 \mathrm{~mm}, 20-50 \mathrm{~mm}$, and $>50 \mathrm{~mm}$, respectively; (C1-C6) are the variations in soil moisture content in the $C$. lanceolata forest under rainfall intensities of $\leq 2 \mathrm{~mm}, 2-10 \mathrm{~mm}, 10-15 \mathrm{~mm}, 15-20 \mathrm{~mm}, 20-50 \mathrm{~mm}$, and $>50 \mathrm{~mm}$, respectively).

The rainfall intensity, soil layer, and land type significantly influenced the initial soil moisture content $(p<0.001)$, except for the effects of soil layers and rainfall on that of Q. acutissima and C. lanceolata (Figure 7). The initial soil moisture content increased with higher rainfall intensity. When the rainfall intensity was $>50 \mathrm{~mm}$, the initial moisture content of the $5 \mathrm{~cm}$ soil layer was significantly higher than that of the other soil layers. When the rainfall intensity was $>50 \mathrm{~mm}$, the initial water content of the grassland, except for the $5 \mathrm{~cm}$ soil layer, was significantly higher than that of the grassland when the rainfall intensity was $\leq 2 \mathrm{~mm}$. (Figure 7A). When the rainfall intensity was $20-50 \mathrm{~mm}$, the initial moisture content of the $5 \mathrm{~cm}$ soil layer of Q. acutissima (Figure 7B) and C. lanceolata (Figure 7C) was significantly higher than that of the other soil layers. The rainfall intensity, soil layer, and land type significantly influenced the average soil moisture content $(p<0.001)$, except for the effects of soil layers on the soil moisture content of Q. acutissima (Figure 8). The average moisture content of the $5 \mathrm{~cm}$ soil layer under the same rainfall intensity was significantly lower than that of the other soil layers $(p<0.05)$ (Figure $8 \mathrm{C})$. The average soil moisture content increased with higher rainfall intensities. With the exception of the $5 \mathrm{~cm}$ soil layer in the Q. acutissima forest, the average moisture content of all the other soil layers was significantly higher under a rain intensity of $\leq 2 \mathrm{~mm}$, in contrast to when the rain intensity was $>50 \mathrm{~mm}$ (Figure 8 ). 


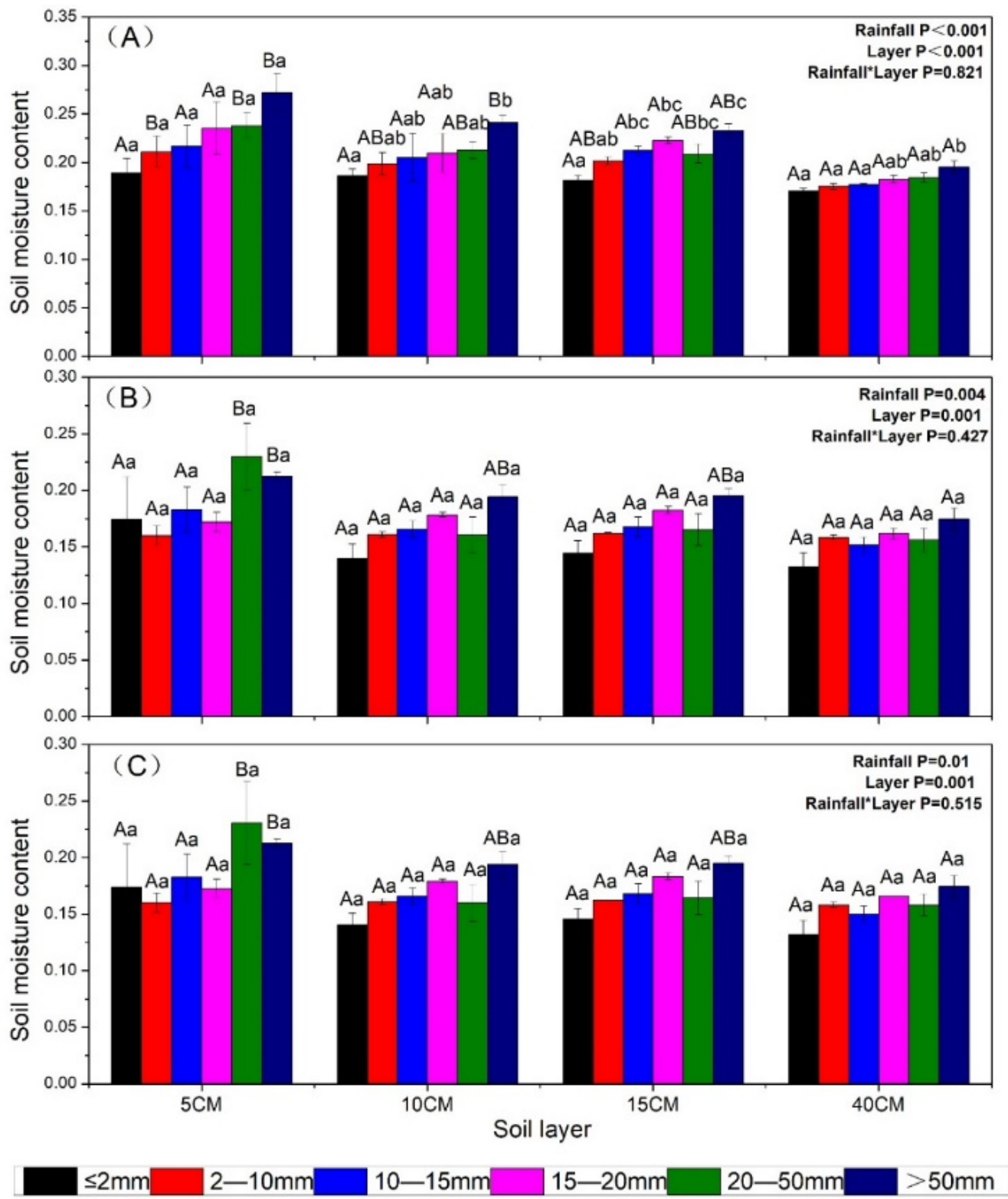

Figure 7. Initial moisture content in grassland, Q. acutissima, and C. lanceolata following different rainfall intensities. (Note: Upper case letters indicate significant differences between different soil layers under the same rainfall intensity $(p<0.05)$; lower case letters indicate significant differences between different rainfall intensities of the same soil layer $(p<0.05)$; (A): grassland ; $(\mathbf{B})$ : Q. acutissima; (C): C. lanceolata; land types: $p<0.001)$.

\subsection{ACR (Absolute Change Rate Value) of Soil Moisture Content Following Rainfall Events}

The rainfall intensity and specific soil layers significantly influenced the ACR (Absolute change rate value) $(p<0.001)$, except for the effects of soil layers on the ACR of $Q$. acutissima. However, the impacts of their interactions were not significant $(p>0.05)$ (Figure 9), and the ACR increased with higher rainfall intensities. When the rainfall intensity ranged from 2-10 $\mathrm{mm}$, the ACR in the $10 \mathrm{~cm}$ and $40 \mathrm{~cm}$ soil layers in grassland was significantly lower than that in the $5 \mathrm{~cm}$ and $15 \mathrm{~cm}$ soil layers, and there were no significant differences between the various soil layers under other rain intensity conditions (Figure 9A). 

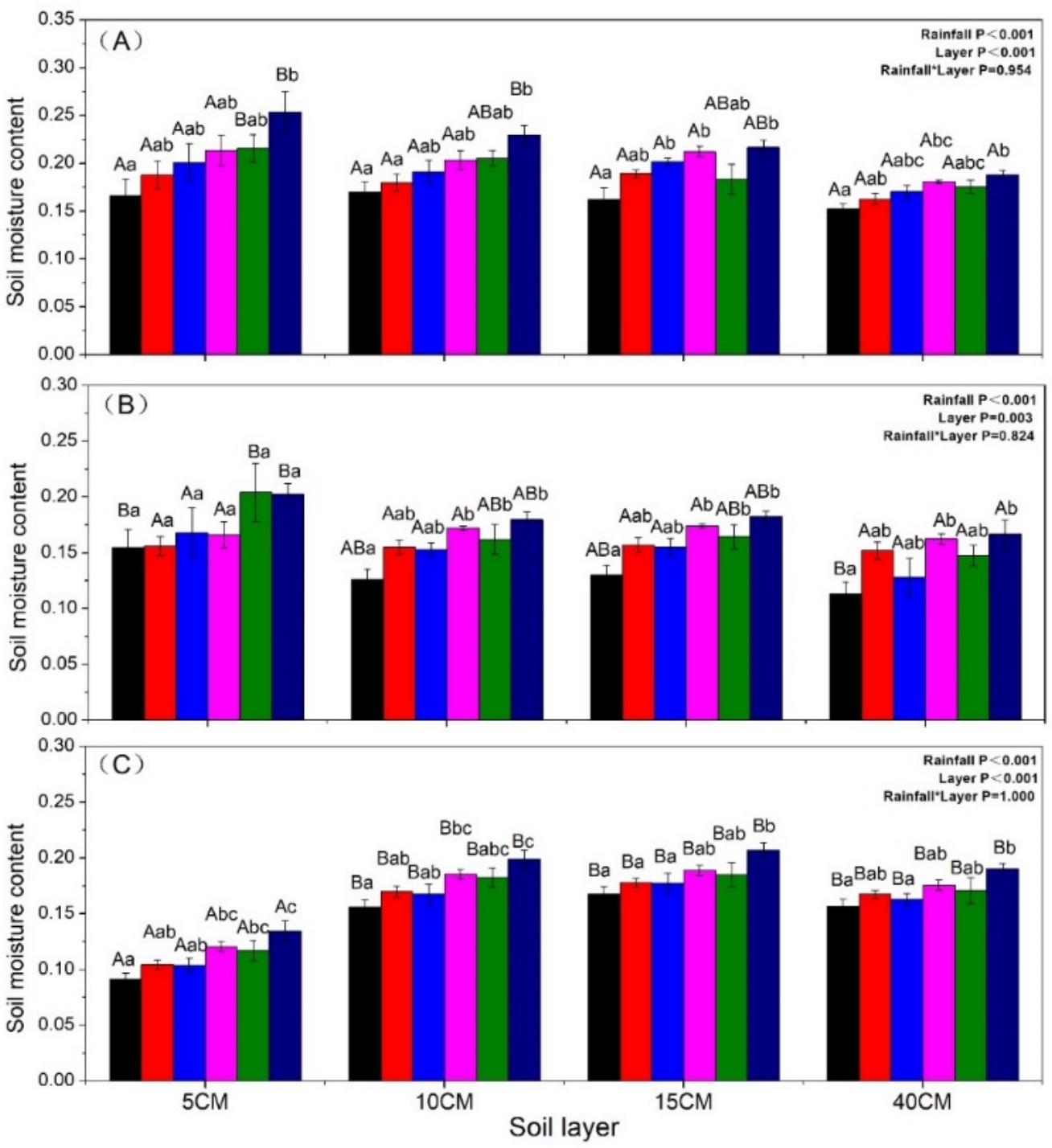

$\leq 2 \mathrm{~mm} \quad 2-10 \mathrm{~mm} \quad 10-15 \mathrm{~mm} \quad 15-20 \mathrm{~mm} \quad 20-50 \mathrm{~mm} \quad>50 \mathrm{~mm}$

Figure 8. Average moisture content in grassland, Q. acutissima, and C. lanceolata following different rainfall intensities. (Note: Upper case letters indicate significant differences between various soil layers under the same rainfall intensity $(p<0.05)$; lower case letters indicate significant differences between different rainfall intensities of the same soil layer $(p<0.05)$; $(\mathbf{A})$ : grassland; $(\mathbf{B})$ : $Q$. acutissima; (C): C. lanceolata; land types: $p<0.001)$.

The ACR of the $40 \mathrm{~cm}$ soil layer was significantly lower than that of the $5 \mathrm{~cm}$ soil layer under rainfall intensities of 2-10 mm, 15-20 mm, and $20-50 \mathrm{~mm}$ in the C. lanceolata forest (Figure 9C). Except for the $5 \mathrm{~cm}$ soil layer of the Q. acutissima forest, the ACR of all the soil layers of all land types was significantly higher when the rainfall intensity was $>50 \mathrm{~mm}$, in contrast to when the rainfall intensity was $\leq 2 \mathrm{~mm}$, or from $2-10 \mathrm{~mm}$ (Figure 9B). The ACR in the C. lanceolata forest was significantly higher than the other rainfall intensities, except for the $5 \mathrm{~cm}$ soil layer at a rainfall intensity of $>50 \mathrm{~mm}$ (Figure 9C).

3.6. Relationships Between the ACR of Soil Moisture Content and Environmental Factors Following Rainfall Events

The RDA of the ACR of the soil moisture content in each layer, and the soil temperature and environmental factors of each layer were considered as explanatory variables. Axis 1 accounted for $59.77 \%$ of the variation in the dataset, with $9.19 \%$ of the variation accounted for by axis 2 (Figure 10). In Figure 8, high ACR 5, ACR 10, ACR 15, and ARC 40 were 
found at the right-hand end of the ordination plots, and were associated with the $\mathrm{P}_{\mathrm{ar}}, \mathrm{V}_{\mathrm{pd}}$, and wind speed. The soil temperature, $\mathrm{T}_{\mathrm{a}}, \mathrm{I}_{5}, \mathrm{~A}_{5}$, and rainfall increased along the y-axis, whereas the $\mathrm{I}_{10}, \mathrm{I}_{15}, \mathrm{I}_{40}, \mathrm{~A}_{10}, \mathrm{~A}_{15}, \mathrm{~A}_{40}$, and $\mathrm{RH}$ decreased.

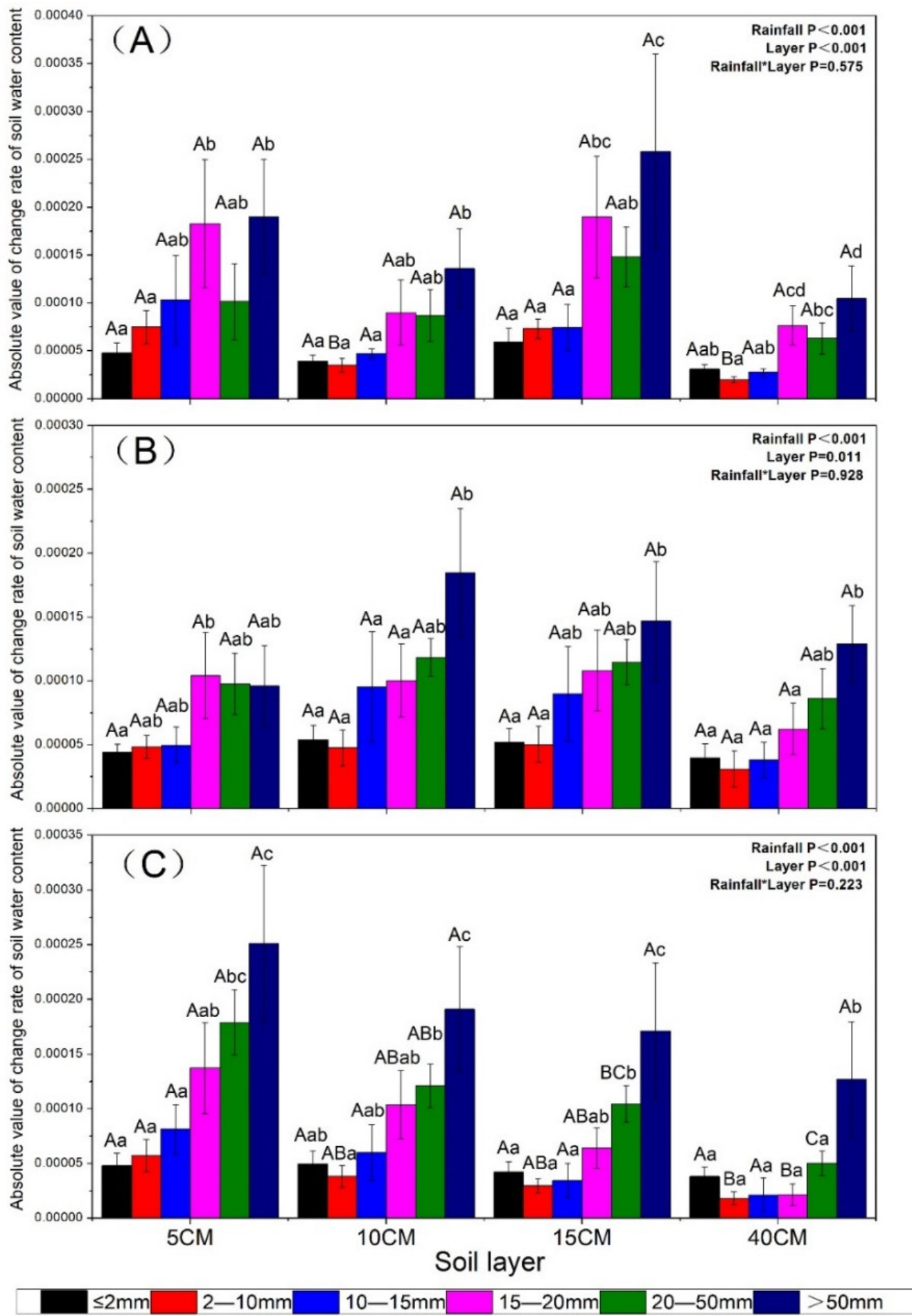

Figure 9. Absolute values of the rates of change in the soil moisture content in grassland, Q.acutissima, and C.lanceolata following different rainfall intensities.(Note: upper case letters indicate significant differences between different soil layers under the same rainfall intensity $(p<0.05)$; lower case letters indicate significant differences between different rainfall intensities in the same soil layer $(p<0.05)$; (A): grassland; (B): Q. acutissima; (C): C. lanceolata; land types: $p=0.198)$. 


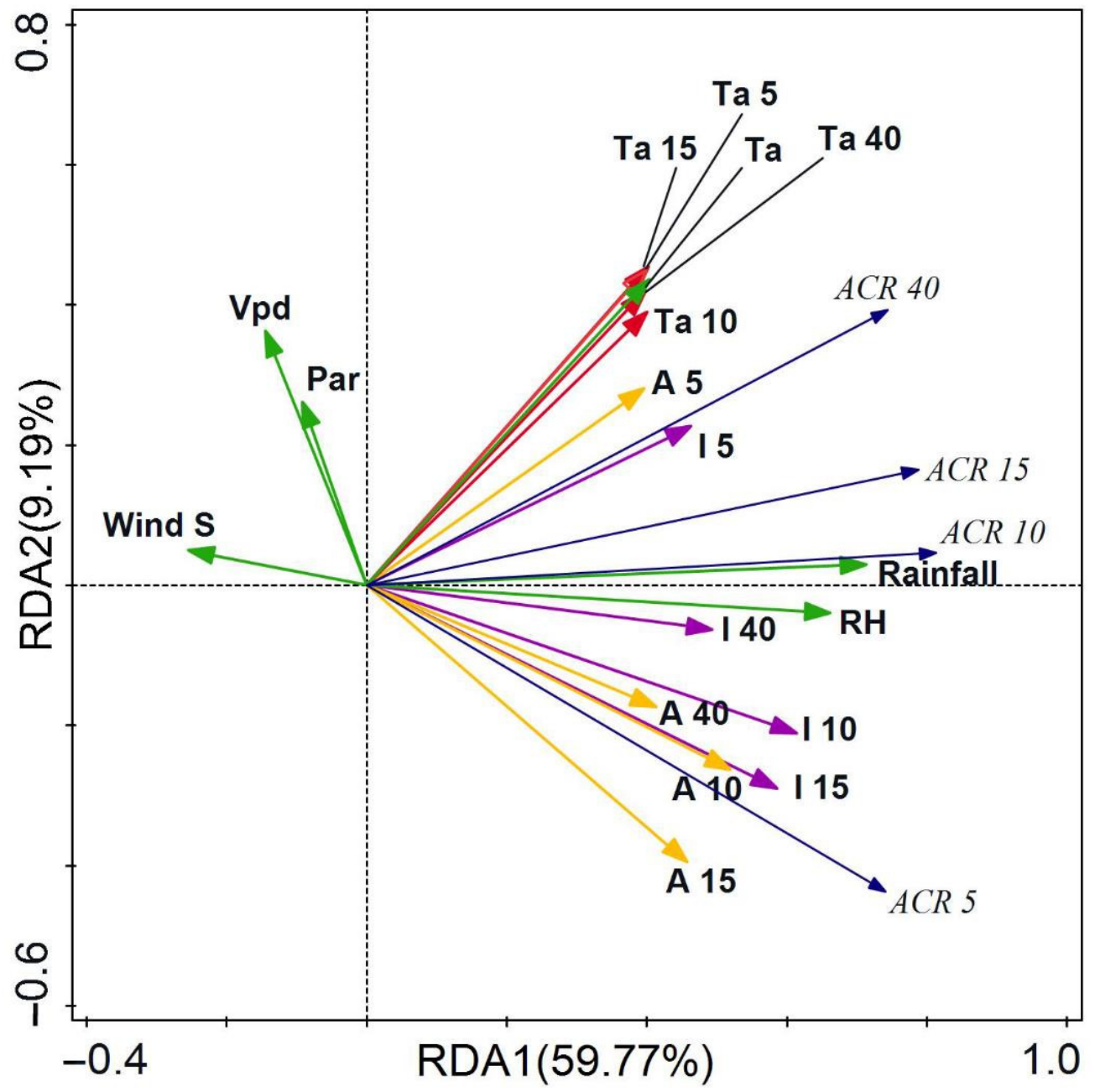

Figure 10. Redundancy analysis (RDA) of the absolute values in the change rates of soil moisture content, soil temperature, soil moisture, and environmental factors. The angles and lengths of arrows indicate the direction and strength of the relationship of the rate of change of soil moisture content, soil temperature, soil moisture, and environmental factors. ACR5, ACR10, ACR15, and ACR40 (blue), respectively, represent the absolute values of the rates of change of the soil moisture content in the $5 \mathrm{~cm}, 10 \mathrm{~cm}, 15 \mathrm{~cm}$, and $40 \mathrm{~cm}$ soil layers; Ta 5, Ta 10, Ta 15, and Ta 40 (red), respectively, represent the soil temperature in the $5 \mathrm{~cm}, 10 \mathrm{~cm}, 15 \mathrm{~cm}$, and $40 \mathrm{~cm}$ soil layers; I 5, I 10, I 15, and I 40 (violet), respectively, represent the initial moisture content in the $5 \mathrm{~cm}, 10 \mathrm{~cm}, 15 \mathrm{~cm}$, and $40 \mathrm{~cm}$ soil layers; A 5, A 10, A 15, and A 40 (yellow), respectively, represent the average moisture content in the $5 \mathrm{~cm}$, $10 \mathrm{~cm}, 15 \mathrm{~cm}$, and $40 \mathrm{~cm}$ soil layers; Par (green): daily mean photosynthetically-active radiation; Ta (green): daily mean air temperature; RH (green): mean air relative humidity; Vpd (green): mean vapor pressure deficit; Rainfall (green): cumulative rainfall; Wind S (green): daily mean wind speed.

\section{Discussion}

Rainfall has always been one of the most heated issues in forest hydrology, to which researchers worldwide have paid close attention. Rainfall leads to the immediate modification of soil moisture [51], which is directly related to the degree of localized drought. It is typically assumed that drought exists only in arid and semi-arid regions; however, the rapid loss of soil water in non-arid areas can cause localized drought, seriously threaten the growth of local vegetation, and further aggravate soil and water loss in non-arid areas. Conversely, when the soil has a strong water retention capacity, the soil water content decreases slowly following rainfall, which is not easily prone to drought and more conducive to plant growth. 
Serious water shortages and quality issues occur in many regions [52,53], particularly in the Yangtze River Delta region of China. Therefore, it is of particular importance to study rainfall and soil moisture in areas with more plentiful water resources. This enables us to make full use of water resources and has important implications for the management of planted forests. For this study, three different land types were selected, and environmental factors such as rainfall and soil water data were collected to quantify soil water changes under different rainfall intensities, as well as to determine the main environmental factors that affected changes in soil water.

The localization and monitoring of soil moisture, rainfall and other environmental factors through the use of relevant EM50 kits has been widely employed in the study of soil hydrology [47]. In this study, although the number of rainfall events with amounts of $\leq 2 \mathrm{~mm}$ accounted for the largest proportion during the overall study period, it had the lowest contribution to the total precipitation. In contrast, the lowest proportion of $>50 \mathrm{~mm}$ rainfall events accounted for nearly a quarter of the total rainfall. Similar results have also been found in other regions [35].

Seasonal variations in precipitation provide a basis for the further study of rainfall and soil moisture. Higher rainfall events during summer and autumn directly increase the soil moisture content, while lower temperatures during the winter and spring lead to a reduction in rainfall in conjunction with a decrease of evaporation, which is the indirect cause of the low soil moisture content [54]. There is sufficient evidence to suggest that these changes alter the physical and chemical properties of the soil due to changes in rainfall, temperature [55], and other environmental factors across the different seasons. In this study, variabilities in the content of soil moisture during the summer and autumn were greater than during the winter and spring [56], which may have been caused by rising temperatures and increased rainfall during summer and autumn, respectively.

However, variations in the soil moisture content is minimal in winter, which may be due to changes in the pore structures of soil caused by lower temperatures, which can significantly limit water transport. Simultaneously, research has indicated that variabilities in the water content of deeper soil layers were lower than that of shallow soil layers, which was due to the shallow soil layers being more susceptible to the vagaries of the external environment [57]. We also found that the soil moisture content of the $5 \mathrm{~cm}$ soil layer (except in the Chinese fir forest) in the spring was significantly higher than that of the other soil layers [58]. This may have been because the rainfall was temporarily stored within the surface layer [59], after which soil water slowly seeped into the deeper soil layers subsequent to increased rainfall. Moreover, this trend may be modified over time, where increased rainfall and the water storage capacity of the surface soil are decreased, and the SWC is increased with greater soil depths [60].

In previous studies, changes in soil moisture were investigated in different areas and habitats [61-64]. Discerning changes in soil moisture is a very complex process, as it is not only affected by the length of precipitation events [24], but also by precipitation intensity [65], vegetation type, soil texture, and other factors. The soil moisture content of grassland was higher than that of the other vegetation types, which may have been attributed to the soil compaction of Q. acutissima and C. lanceolata forests, and poor ground cover under the trees [35].

As is well acknowledged, the canopies of arbor trees have interceptive effects on rainfall. In contrast to Grassland, the canopies of Q. acutissima and C. lanceolata had less rainwater that directly reached the ground to supplement soil moisture, where a large proportion of rainfall was intercepted by and evaporated from the canopy. The ACR of the $40 \mathrm{~cm}$ soil layer in grassland and C. lanceolata forest was lower than that of the other soil layers, which may have been due to the influence of shallow water transport channels in the grassland and C. lanceolata forest. We found that the variation coefficient of soil moisture content in the $5 \mathrm{~cm}$ soil layer was: C. lanceolata forests $>$ grassland $>Q$. acutissima forests (Figure 11A). The C. lanceolate was a coniferous forest; thus, the interceptive functions of the plants were small. Grass could well cover the surface of bare land, while Q. acutissima was 
a broadleaved forest, which possessed a better interlocking effect, such that less rainfall made it to the ground, and the variation coefficient of soil water content was smaller.
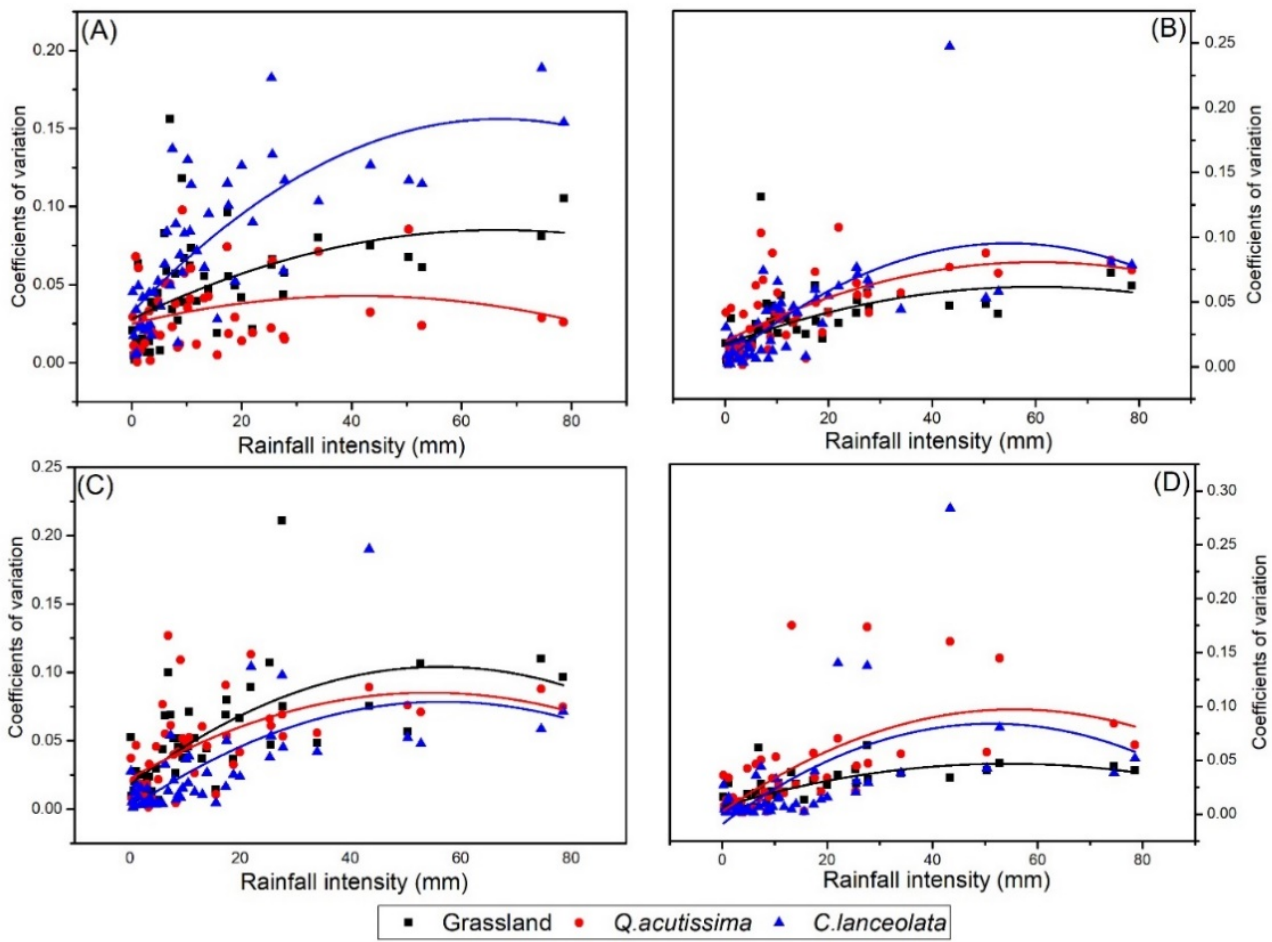

Figure 11. Variation coefficient of soil moisture content with different rainfall intensities (A), $5 \mathrm{~cm}$ soil layer (B), $10 \mathrm{~cm}$ soil layer (C), $15 \mathrm{~cm}$ soil layer (D), $40 \mathrm{~cm}$ soil layer.

The water loss in shallow soil was more rapid following rainfall. Since Q. acutissima is a deep-rooted tree its root systems can penetrate deeply into the soil and provide water transfer channels, so that the ACR of the deep soil is not too low. In this study, the initial and average moisture content of the $5 \mathrm{~cm}$ soil layer of the $C$. lanceolata forest was significantly lower than that of the other soil layers. This may have been due to the fact that under the action of canopy interception there was less water available to enter the soil, and the coniferous litter layer was not conducive to water storage. Furthermore, direct sunlight facilitated the increased evaporation of surface water.

Soil is directly impacted by rainfall, which has a potent influence on surface and deep soil structures, as well as changes in soil moisture [24]. We found that both the initial and average soil moisture content and ACR were greater when the rainfall intensity was $\leq 2 \mathrm{~mm}$, in contrast to when the rainfall intensity was $>50 \mathrm{~mm}$. This may have been due to the fact that low amounts rainfall induced soil particles to aggregate through low cohesion forces [66,67], which resulted in the formation of a crust on the soil surface following rainfall, making it more difficult for water to enter into the deep soil [68]. This phenomenon can lead to more frequent and long-term drought conditions within the surface soil [69], while strong rainfall can cause more water to infiltrate into and supplement the deep soil layers [70,71]. In this study, it was revealed that changes in rainfall intensity caused changes in the soil moisture content at different depths (Figure 11). Under the same rainfall intensity, the variation coefficient of the water content in shallow soil was larger (Figure 11A), because it was more susceptible to other environmental factors in addition to rainfall.

Strong rainfall events facilitated the transport of water into the deep soil layers, while simultaneously establishing and connecting water transport channels within the soil. Consequently, the ACR under heavy rainfall intensities were also larger, and water was more easily lost through the walls of the water transport channels. With higher precipitation, the soil moisture content increased within the deeper soil layers [72]. We also found that high rainfall intensities enhanced the soil moisture content, albeit not 
significantly. This may have been due to the buildup of runoff following high intensity rainfall [73], which can disrupt shallow soil structures [42]. Since the influence of increased water content on soil infiltration was gradually lessened [74] the infiltration rate was reduced [75]. Rainfall is a critical link in the hydrological cycle, and each link of the hydrological cycle does not exist in isolation; thus, any variation in one link can initiate a cascading chain reaction. Rainfall increased the soil moisture content and air humidity, after which the soil and air temperature decreased; thus, affecting plant growth, which in turn altered transpiration dynamics and affected rainfall.

Environmental factors that affected the ACR primarily included the initial soil moisture content, average soil moisture content, soil temperature, $\mathrm{T}_{\mathrm{a}}$, rainfall, $\mathrm{RH}$, and more [76]. The initial and average soil moisture content were positively correlated with the ACR, which was consistent with previous research results [25]. The reason may have been that the higher soil moisture content served as a prerequisite for soil moisture loss, where water channels within the soil were opened by the original soil moisture; thus, water loss occurred much easier [77].

Compared with deep soil, correlations between the ACR in shallow soil and soil moisture were weak, which may have been related to the fact that shallow soil was more susceptible to the variabilities of the external environment. The soil and air temperature had no significant influence on the ACR of the surface soil, while the ACR was positively correlated with temperature in the soil layer below $5 \mathrm{~cm}$ [78]. This may have been due to the evaporation of soil water at higher temperatures and affected by the soil water content [79]. Further, wind expedited the transpiration of plants and soil, thus causing the loss of surface water.

Since the transpiration of plants induced deep soil moisture to supplement the surface [80], the ACR of the surface soil was most vulnerable to the impacts of precipitation, air flow, air temperature, and so on, which could rapidly increase or decrease. Deep soil consumes water primarily due to the action of meteorological factors on plants [81,82]. Simultaneously, because of the single vertical structures of tree species at the test site, air flow more easily passed through the forest canopy. Therefore, the two factors above became critical factors that initiated changes in the soil ACR.

It is worth noting that this study undertook only one year of field monitoring. Simultaneously, the soil organic matter content was believed to affect the soil water content and water storage [51], whereas topographic factors also had an impact on the soil water content. This aspect of the index should be included in future studies.

\section{Conclusions}

Following a one-year location monitoring experiment, different rainfall intensities and environmental factors were observed to have significant influences on the soil moisture of a typical plantation in the Yangtze River Delta. The variability of soil water during the summer $\left(C_{v}=0.231\right)$ and autumn $\left(C_{v}=0.0 .170\right)$ was stronger than during the winter $\left(C_{v}=0.0 .055\right)$. Compared with shallow soil, water variability in the deep soil $\left(C_{v}=0.117\right)$ was decreased, and the shallow soil was more susceptible to the influences of external environmental factors. With higher rainfall intensities, the initial and average moisture content and the ACR of the soil increased correspondingly. Strong rainfall was more conducive to the infiltration and migration of soil water, and deep-rooted tree species such as Q. acutissima were more favorable for the migration of deep soil water. Furthermore, the ACR was susceptible to environmental factors such as soil temperature, soil moisture, $\mathrm{P}_{\mathrm{ar}}(\gamma=-0.29), \mathrm{RH}(\gamma=0.46)$, and wind speed. In other areas with similar or different soil moisture conditions, the dynamic monitoring of soil moisture should be strengthened, particularly before and after rainfall events. A detailed set of principles that reflect changes in soil water dynamics should be developed to facilitate scientific planning and guidance toward the optimal cultivation of artificial forests, or the protection of natural forests. In this study, we collected and analyzed meteorological, soil moisture, and temperature data for only one year; hence, there were some limitations in the analytical results. In future 
studies, soil physical and chemical indexes should be combined for analysis, whereas meteorological, soil moisture temperature data might be collected for a longer period of time to improve the reliability of the study. In summary, we believe that future changes in soil moisture may have increasingly profound impacts on forest ecology and hydrology, which will be progressively driven by rapidly changing environmental conditions due to global warming.

Author Contributions: Conceptualization, Y.T. and X.L.; methodology, Y.T. and X.L.; software, Y.T. and X.L.; validation, Y.T., X.L., X.C. and C.L.; formal analysis, Y.T. and X.L.; investigation, Y.T. and X.L.; resources, Y.T. and X.L.; data curation, Y.T. and X.L.; writing—original draft preparation, Y.T. and X.L.; writing — review and editing, Y.T. and X.L.; visualization, Y.T. and X.L.; supervision, Y.T., X.L., Z.J., S.M., L.Z. and B.Z.; project administration, Y.T. and X.L.; funding acquisition, Y.T., X.L. and J.Z. All authors have read and agreed to the published version of the manuscript.

Funding: This research received no external funding.

Institutional Review Board Statement: Not applicable.

Data Availability Statement: Not applicable.

Acknowledgments: This research was supported by the Natural Science Foundation for Youth of Jiangsu Province (BK20200785), National Special Fund for Forestry Scientific Research of the Jiangsu Agriculture Science, Technology Innovation Fund (Grant No. CX (17)1004), Priority Academic Program Development of Jiangsu Higher Education Institutions (PAPD), and China Postdoctoral Science Foundation (2018M642260). We would like to thank Frank Boehm, from Lakehead University, for the language editing of this manuscript.

Conflicts of Interest: The authors declare no conflict of interest.

\section{Appendix A}
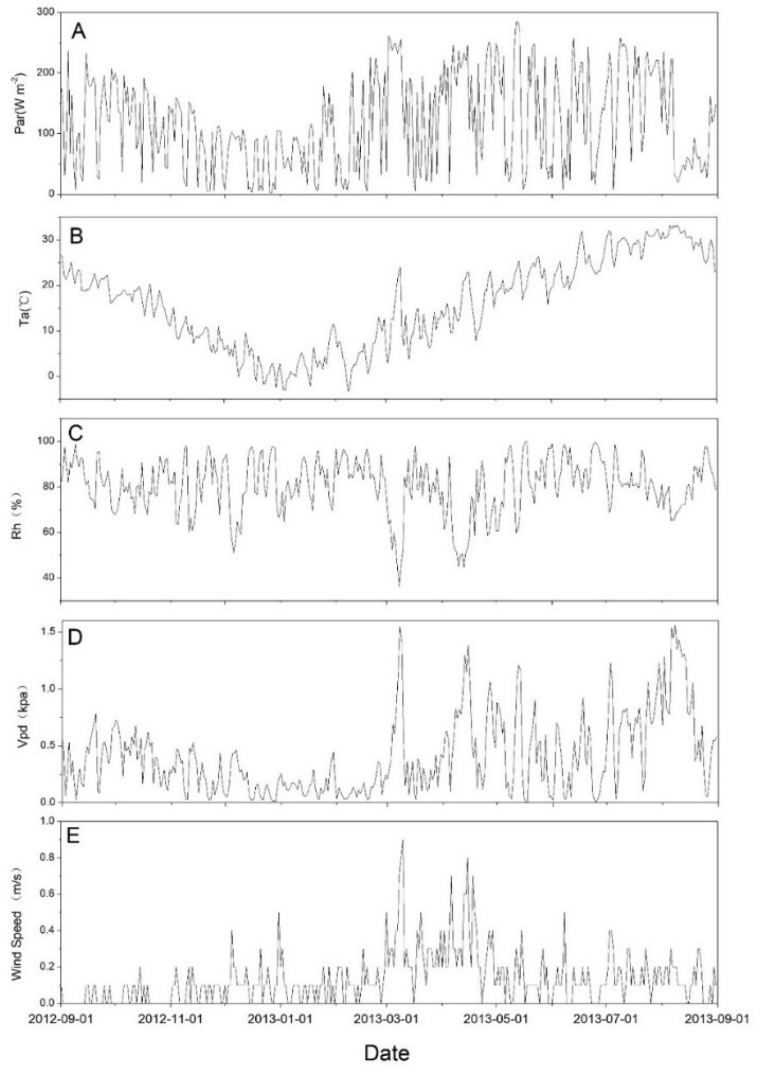

Figure A1. Seasonal course of daily mean photosynthetically-active radiation. $\left(\mathrm{P}_{\mathrm{ar}}\right)(\mathrm{A})$, daily mean air temperature $\left(T_{a}\right)(B)$, mean air relative humidity $\left(R_{h}\right)(C)$, mean vapor pressure deficit $\left(V_{p d}\right)(D)$, mean wind speed (E) between 9 September 2012 and 8 August 2013. 


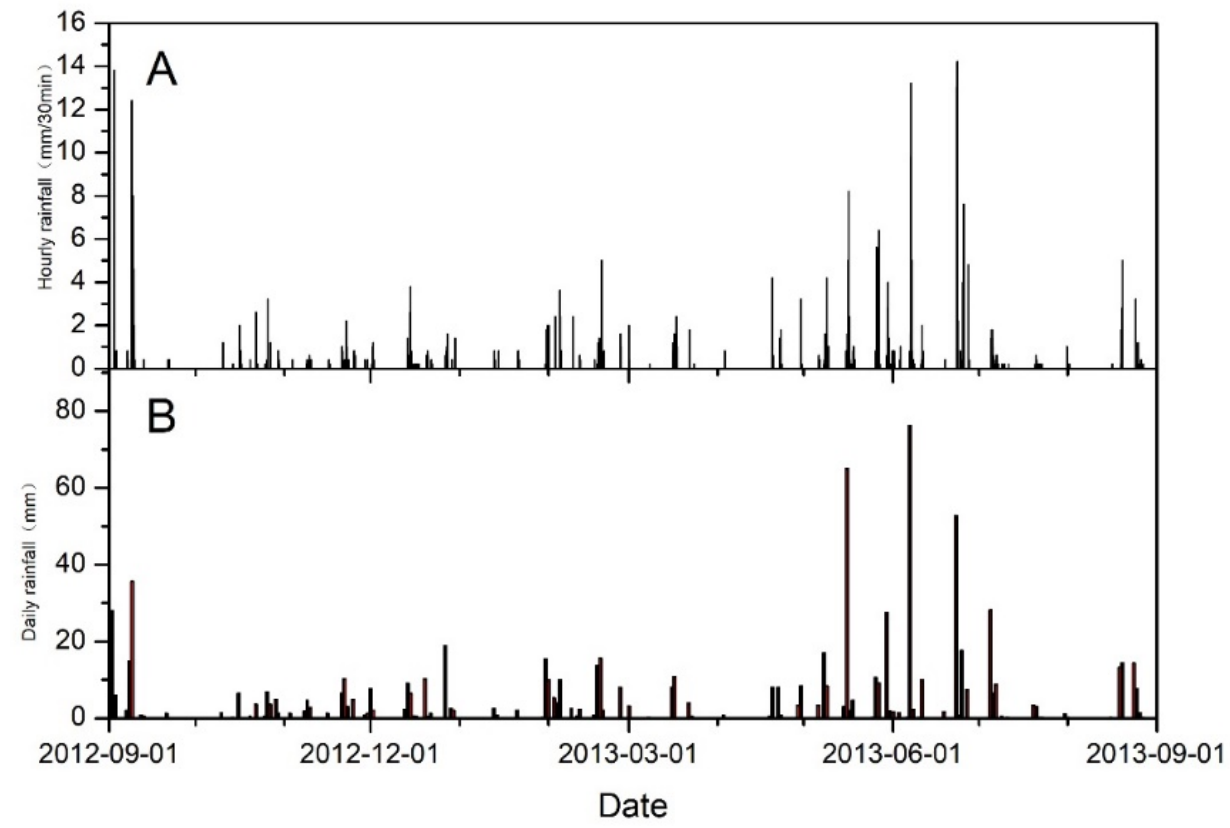

Figure A2. Rainfall measurements ((A): half-hourly rainfall; (B): daily rainfall).

\section{References}

1. Zhi, D.; Jue, H.; Qianhui, X.; Qiang, F.; Peng, H.; Rui, L. Analysis on characteristics and development countermeasures of olantation reesources in China. Cent. South. For. Inventory Plan. 2020, 39, 5-10.

2. Bindlish, R.; Jackson, T.J.; Wood, E.; Gao, H.; Starks, P.; Bosch, D.; Lakshmi, V. Soil moisture estimates from TRMM Microwave Imager observations over the Southern United States. Remote Sens. Environ. 2003, 85, 507-515. [CrossRef]

3. Schneider, K.; Huisman, J.A.; Breuer, L.; Zhao, Y.; Frede, H.G. Temporal stability of soil moisture in various semi-arid steppe ecosystems and its application in remote sensing. J. Hydrol. 2008, 359, 16-29. [CrossRef]

4. Puri, S.; Stephen, H.; Ahmad, S. Relating TRMM precipitation radar land surface backscatter response to soil moisture in the Southern United States. J. Hydrol. 2011, 402, 115-125. [CrossRef]

5. Zhi-Bin, H.; Zhao, W. Variability of soil moisture of shifting sandy land and its dependence on precipitation in semi-arid region. $J$. Desert Res. 2002, 22, 359-362. [CrossRef]

6. Bergkamp, G. A hierarchical view of the interactions of runoff and infiltration with vegetation and microtopography in semiarid shrublands. Catena 1998, 33, 201-220. [CrossRef]

7. Svetlitchnyi, A.A.; Plotnitskiy, S.V.; Stepovaya, O.Y. Spatial distribution of soil moisture content within catchments and its modelling on the basis of topographic data. J. Hydrol. 2003, 277, 50-60. [CrossRef]

8. Fu, B.; Chen, L.; Ma, K.; Zhou, H.; Wang, J. The relationships between land use and soil conditions in the hilly area of the loess plateau in northern Shaanxi, China. Catena 2000, 39, 69-78. [CrossRef]

9. Shu-xia, Y.; Tong-hui, Z.; Chuan-cheng, Z.; Xin-ping, L. Spatio-temporal Variability of Soil Moisture in Different Dunes of Horqin Sandy Land. J. Soil Water Conserv. 2012, 26, 251-258. [CrossRef]

10. Reynolds, J.F.; Kemp, P.R.; Ogle, K.; Fernández, R.J. Modifying the 'pulse-reserve' paradigm for deserts of North America: Precipitation pulses, soil water, and plant responses. Oecologia 2004, 141, 194-210. [CrossRef]

11. Seneviratne, S.I.; Corti, T.; Davin, E.L.; Hirschi, M.; Jaeger, E.B.; Lehner, I.; Orlowsky, B.; Teuling, A.J. Investigating soil moisture-climate interactions in a changing climate: A review. Earth-Sci Rev. 2010, 99, 125-161. [CrossRef]

12. Getie, M.A.; Legesse, S.A.; Mekonnen, M.; Aschalew, A. Environment. Soil Properties and Crop Productivity Strategies as a Potential Climate Variability Adaptation Options in Adefwuha Watershed, Ethiopia. Earth Syst. Environ. 2020, 4, 359-368. [CrossRef]

13. Rodrigo-Comino, J.; Terol, E.; Mora, G.; Giménez-Morera, A.; Cerdà, A. Vicia sativa Roth. Can Reduce Soil and Water Losses in Recently Planted Vineyards (Vitis vinifera L.). Earth Syst. Environ. 2020, 4, 827-842. [CrossRef]

14. Brocca, L.; Tullo, T.; Melone, F.; Moramarco, T.; Morbidelli, R. Catchment scale soil moisture spatial—temporal variability. J. Hydrol. 2012, 422, 63-75. [CrossRef]

15. Owe, M.; Jones, E.B.; Schmugge, T.J. Soil Moisture Variation Patterns Observed in Hand County, South Dakota. Jawra J. Am. Water Resour. Assoc. 2010, 18, 949-954. [CrossRef]

16. Zheng, H.; Gao, J.; Teng, Y.; Feng, C.; Tian, M. Temporal Variations in Soil Moisture for Three Typical Vegetation Types in Inner Mongolia, Northern China. PLoS ONE 2015, 10, e0118964. [CrossRef]

17. Bin, W.; Pengtao, Y.; Shunli, W.; Yanhui, W.; Xuelong, Z. Effects of moss layers on the spatial variation in soil moisture in a Picea crassifolia forest on the north-facing slope of the Qilian Mountains. Acta Ecol. Sin. 2017, 37. 
18. Yong, L.; Chen, J.; Lin, L.; Wang, S. Spatial and temporal variability of soil moisture in hilly red soil region based on land use and microtopography. Trans. Chin. Soc. Agric. Eng. 2009, 25, 36-41.

19. Chen, X.F.; Xi, C.; Ju, W.M.; Ren, L.L.; Liang, C.Y. Comparison of the Temporal Heterogeneity of Soil Moisture of Different Ecosystems at Red Soil Hillside Fields. Adv. Mater. Res. 2012, 455, 1361-1365. [CrossRef]

20. Constantinidou, K.; Hadjinicolaou, P.; Zittis, G.; Lelieveld, J. Performance of Land Surface Schemes in the WRF Model for Climate Simulations over the MENA-CORDEX Domain. Earth Syst. Environ. 2020, 4, 647-665. [CrossRef]

21. Wang, S.; Fu, B.; Gao, G.; Liu, Y.; Zhou, J. Responses of soil moisture in different land cover types to rainfall events in a re-vegetation catchment area of the Loess Plateau, China. Catena 2013, 101, 122-128. [CrossRef]

22. Famiglietti, J.S.; Rudnicki, J.W.; Rodell, M. Variability in surface moisture content along a hillslope transect: Rattlesnake Hill, Texas. J. Hydrol. 1998, 210, 259-281. [CrossRef]

23. Zhang, Y.; Liu, J.; Xu, X.; Tian, Y.; Li, Y.; Gao, Q. The response of soil moisture content to rainfall events in semi-arid area of Inner Mongolia. Procedia Environ. Sci. 2010, 2, 1970-1978. [CrossRef]

24. Heisler-White, J.L.; Knapp, A.K.; Kelly, E.F. Increasing precipitation event size increases aboveground net primary productivity in a semi-arid grassland. Oecologia 2008, 158, 129-140. [CrossRef]

25. Shouqin, Z.; Weihua, Z.; Jiake, L.; Chaofu, W. Temporal variation of soil water and its influencing factors in hilly area of Chongqing, China. Int. J. Agric. Biol. Eng. 2014, 7, 47-59.

26. Ivanov, V.Y.; Fatichi, S.; Jenerette, G.D.; Espeleta, J.F.; Troch, P.A.; Huxman, T.E. Hysteresis of soil moisture spatial heterogeneity and the "homogenizing" effect of vegetation. Water Resour. Res. 2010, 46. [CrossRef]

27. Western, A.W.; Blöschl, G. On the spatial scaling of soil moisture. J. Hydrol. 1999, 217, 203-224. [CrossRef]

28. Western, A.W.; Grayson, R.B.; Blöschl, G.; Willgoose, G.R.; McMahon, T.A. Observed spatial organization of soil moisture and its relation to terrain indices. Water Resour. Res. 1999, 35, 797-810. [CrossRef]

29. Qiu, Y.; Fu, B.; Wang, J.; Chen, L. Soil moisture variation in relation to topography and land use in a hillslope catchment of the Loess Plateau, China. J. Hydrol. 2001, 240, 243-263. [CrossRef]

30. Qiu, Y.; Fu, B.; Wang, J.; Chen, L. Spatial variability of soil moisture content and its relation to environmental indices in a semi-arid gully catchment of the Loess Plateau, China. J. Arid Environ. 2001, 49, 723-750. [CrossRef]

31. Moore, I.D.; Burch, G.J.; Mackenzie, D.H. Topographic Effects on the Distribution of Surface Soil Water and the Location of Ephemeral Gullies. Trans. ASAE 1988, 31, 1098-1107. [CrossRef]

32. Troeh, F.R. Landform Parameters Correlated to Soil Drainage. Soil Sci. Soc. Am. J. 1964, 28, 808-812. [CrossRef]

33. Morris, R.C.; Fraley Jr, L. Soil permeability as a function of vegetation type and soil water content. Health Phys. 1994, 66, 691. [CrossRef]

34. Lan, Z.L.; Pan, X.L.; Zhao, Y.; Si, B.C.; Wang, Y.K.; Jiao, R.; Zhang, J.G. Effects of land use types on deep soil water content in the loess hilly area of the north Shaanxi Province, China. J. Appl. Ecol. 2017, 28, 847-855.

35. Chen, L.; Huang, Z.; Gong, J.; Fu, B.; Huang, Y. The effect of land cover/vegetation on soil water dynamic in the hilly area of the loess plateau, China. Catena 2007, 70, 200-208. [CrossRef]

36. Flores-Mangual, M.L.; Lowery, B.; Bockheim, J.G.; Pagliari, P.H.; Scharenbroch, B. Hydrophobicity of Sparta Sand under Different Vegetation Types in the Lower Wisconsin River Valley. Soil Sci. Soc. Am. J. 2013, 77, 1506-1516. [CrossRef]

37. Cho, E.; Choi, M. Regional scale spatio-temporal variability of soil moisture and its relationship with meteorological factors over the Korean peninsula. J. Hydrol. 2014, 516, 317-329. [CrossRef]

38. Lakshmi, V.; Jackson, T.J.; Zehrfuhs, D. Soil moisture-temperature relationships: Results from two field experiments. Hydrol. Process. 2003, 17, 3041-3057. [CrossRef]

39. Giraldo, M.A.; Bosch, D.; Madden, M.; Usery, L.; Finn, M. Ground and surface temperature variability for remote sensing of soil moisture in a heterogeneous landscape. J. Hydrol. 2009, 368, 214-223. [CrossRef]

40. Salve, R.; Sudderth, E.A.; Clair, S.S.B.; Torn, M.S. Effect of grassland vegetation type on the responses of hydrological processes to seasonal precipitation patterns. J. Hydrol. 2011, 410, 51-61. [CrossRef]

41. Yao, S.X.; Zhao, C.C.; Zhang, T.H.; Liu, X.P. Response of the soil water content of mobile dunes to precipitation patterns in Inner Mongolia, northern China. J. Arid Environ. 2013, 97, 92-98. [CrossRef]

42. Hawke, R.M.; Price, A.G.; Bryan, R.B. The effect of initial soil water content and rainfall intensity on near-surface soil hydrologic conductivity: A laboratory investigation. Catena 2006, 65, 237-246. [CrossRef]

43. Liu, X.; He, Y.; Zhang, T.; Zhao, X.; Li, Y.; Zhang, L.; Wei, S.; Yun, J.; Yue, X. The response of infiltration depth, evaporation, and soil water replenishment to rainfall in mobile dunes in the Horqin Sandy Land, Northern China. Environ. Earth Sci. 2015, 73, 8699-8708. [CrossRef]

44. Li, X.R.; Ma, F.Y.; Xiao, H.L.; Wang, X.P.; Kim, K.C. Long-term effects of revegetation on soil water content of sand dunes in arid region of Northern China. J. Arid Environ. 2004, 57, 1-16. [CrossRef]

45. Yang, Q.-H.; Chen, L.-H.; Zhang, F.; Zhang, C. Responses of soil moisture variations to rainfall and vegetation. Beijing Linye Daxue Xuebao/J. Beijing For. Univ. 2008, 30, 88-94.

46. Borhan, M.S.; Parsons, L.R. Monitoring of Soil Water Content in a Citrus Grove Using Capacitance ECH2O Probes; American Society of Agricultural and Biological Engineers: St. Joseph, MI, USA, 2004.

47. Liu, X.; Zhang, B.; Zhuang, J.Y.; Han, C.; Zhai, L.; Zhao, W.R.; Zhang, J.C. The Relationship between Sap Flow Density and Environmental Factors in the Yangtze River Delta Region of China. Forests 2017, 8, 74. [CrossRef] 
48. Abdi, H. Coefficient of Variation. In The Encyclopedia of Statistics in Behavioral Science; John Wiley \& Sons, Ltd.: Hoboken, NJ, USA, 2011; Volume 94, p. 94.

49. Hu, W.; Shao, M.; Reichardt, K. Using a New Criterion to Identify Sites for Mean Soil Water Storage Evaluation. Soil Sci. Soc. Am. J. 2010, 74, 762-773. [CrossRef]

50. Fu, Q.; Wang, X.; Wang, Z.; Li, T.; Hou, R.; Osman, A. Analysis of the effects of different snow cover mulches on spatio-Temporal variations of farmland soil moisture. Appl. Eng. Agric. 2015, 31, 919-928. [CrossRef]

51. Wang, G.; Sun, W.; Xue, B.; Kiem, A. Stratification response of soil water content during rainfall events under different rainfall patterns. Hydrol. Process. 2018, 32, 3128-3139.

52. Chen, Q.; Wu, W.; Blanckaert, K.; Ma, J.; Huang, G. Optimization of water quality monitoring network in a large river by combining measurements, a numerical model and matter-element analyses. J. Environ. Manag. 2012, 110, 116-124. [CrossRef]

53. Zeng, Z.; Liu, J.; Savenije, H.H.G. A simple approach to assess water scarcity integrating water quantity and quality. Ecol. Indic. 2013, 34, 441-449. [CrossRef]

54. Chen, M.; Willgoose, G.R.; Saco, P.M. Spatial prediction of temporal soil moisture dynamics using HYDRUS-1D. Hydrol. Process. 2014, 28, 171-185. [CrossRef]

55. Kocárek, M.; Kodesova, R. Influence of temperature on soil water content measured by ECH2O-TE sensors. Int. Agrophys. 2012, 26, 259-269. [CrossRef]

56. Illston, B.G.; Basara, J.B.; Crawford, K.C. Seasonal to interannual variations of soil moisture measured in Oklahoma. Int. J. Climatol.: J. R. Meteorol. Soc. 2004, 24, 1883-1896. [CrossRef]

57. Zhao, W.; Cui, Z.; Zhou, C. Spatiotemporal variability of soil-water content at different depths in fields mulched with gravel for different planting years. J. Hydrol. 2020, 590, 125253. [CrossRef]

58. Li, X.Y. Gravel-sand mulch for soil and water conservation in the semiarid loess region of northwest China. Catena 2003, 52, 105-127. [CrossRef]

59. Penna, D.; Brocca, L.; Borga, M.; Dalla Fontana, G. Soil moisture temporal stability at different depths on two alpine hillslopes during wet and dry periods. J. Hydrol. 2013, 477, 55-71. [CrossRef]

60. Abagale, F.K.; Tetteh, G.A. SOIL WATER CONTENT PROFILING USING EnviroSMART IN NORTHERN GHANA. Acad. J. 2011, 2, 2141-2391.

61. Hu, W.; Shao, M.A.; Wang, Q.J.; Reichardt, K. Soil water content temporal-spatial variability of the surface layer of a Loess Plateau hillside in China. Sci. Agric. 2008, 65, 277-289. [CrossRef]

62. Bahrawi, J.A.; Elhag, M. Consideration of seasonal variations on water radiometric indices estimation of soil moisture content in arid environment in Saudi Arabia. Desalination Water Treat. 2020, 176, 201-212. [CrossRef]

63. Yu, Y.; Wei, W.; Chen, L.D.; Jia, F.Y.; Yang, L.; Zhang, H.D.; Feng, T.J. Responses of vertical soil moisture to rainfall pulses and land uses in a typical loess hilly area, China. Solid Earth 2015, 6, 595-608. [CrossRef]

64. Zhao, J.; Pan, W.; Wul, J.; Yang, Y. Assessment of the impact of soil moisture on spring surface air temperature over the low-latitude highlands of China. Int. J. Climatol. 2020, 40, 6629-6645. [CrossRef]

65. Yaseef, N.R.; Yakir, D.; Rotenberg, E.; Schiller, G.; Cohen, S. Ecohydrology of a semi-arid forest: Partitioning among water balance components and its implications for predicted precipitation changes. Ecohydrol.: Ecosyst. Land Water Process Interact. Ecohydrogeomorphol. 2010;3, 143-154.

66. Ben-Hur, M.; Lado, M. Effect of soil wetting conditions on seal formation, runoff, and soil loss in arid and semiarid soils-A review. Soil Res. 2008, 46, 191-202. [CrossRef]

67. García-Orenes, F.; Roldán, A.; Mataix-Solera, J.; Cerdà, A.; Campoy, M.; Arcenegui, V.; Caravaca, F. Soil structural stability and erosion rates influenced by agricultural management practices in a semi-arid Mediterranean agro-ecosystem. Soil Use Manag. 2012, 28, 571-579. [CrossRef]

68. Ziadat, F.M.; Taimeh, A.Y. Effect of rainfall intensity, slope, land use and antecedent soil moisture on soil erosion in an arid environment. Land Degrad. Dev. 2013, 24, 582-590. [CrossRef]

69. Thomey, M.L.; Collins, S.L.; Vargas, R.; Johnson, J.E.; Brown, R.F.; Natvig, D.O.; Friggens, M.T. Effect of precipitation variability on net primary production and soil respiration in a Chihuahuan Desert grassland. Glob. Chang. Biol. 2011, 17, 1505-1515. [CrossRef]

70. Wei, Y.; Guo, K.; Chen, J. Effect of precipitation pattern on recruitment of soil water in Kubuqi desert, northwestern China. J. Plant. Ecol. 2008, 32, 1346-1355.

71. Huxman, T.E.; Snyder, K.A.; Tissue, D.; Leffler, A.J.; Schwinning, S. Precipitation pulses and carbon fluxes in semiarid and arid ecosystems. Oecologia 2004, 141, 254-268. [CrossRef]

72. Jia, J.; Yu, X.; Li, Y. Response of forestland soil water content to heavy rainfall on Beijing Mountain, northern China. J. For. Res. 2016, 27, 541-550. [CrossRef]

73. Darvishan, A.K.; Banasik, K.; Sadeghi, S.H.; Gholami, L.; Hejduk, L. Effects of Rain Intensity and Initial Soil Moisture on Hydrological Responses in Laboratory Conditions. Int. Agrophys. 2015, 29, 165-173. [CrossRef]

74. Han, L.; Tingwu, L.; Jun, Z. Effects ofinitial soil watercontent and rainfall intensity on Loess infiltrationcapacity. Sci. Soil Water Conserv. 2009, 7, 1-6.

75. Harmel, R.D.; Richardson, C.W.; King, K.W.; Allen, P.M. Runoff and soil loss relationships for the Texas Blackland Prairies ecoregion. J. Hydrol. 2006, 331, 471-483. [CrossRef] 
76. Srivastava, A.; Saco, P.M.; Rodriguez, J.F.; Kumari, N.; Chun, K.P.; Yetemen, O. The role of landscape morphology on soil moisture variability in semi-arid ecosystems. Hydrol. Process. 2020, 35. [CrossRef]

77. Yang, Y.; Jiang, Y.; Zhang, W.; Li, X. Spatial Distribution of Soil Water Content and Its Influential Factors in Transition Zone Along the Treeline of Luya Mountain, Shanxi Province. J. Ecol. Rural Environ. 2012, 28, 120-127.

78. Yoshioka, M.; Takakura, S.; Ishizawa, T.; Sakai, N. Temporal changes of soil temperature with soil water content in an embankment slope during controlled artificial rainfall experiments. J. Appl. Geophys. 2015, 114, 134-145. [CrossRef]

79. Mestas-Valero, R.; Miras-Avalos, J.; Paz-González, A. Assessment of the soil water content temporal variations in an agricultural area of Galicia (NW Spain). In EGU General Assembly Conference Abstracts; European Geosciences Union: Munich, Germany, 2010; Volume 12, p. 3635.

80. Drake, P.L.; Franks, P.J. Water resource partitioning, stem xylem hydraulic properties, and plant water use strategies in a seasonally dry riparian tropical rainforest. Oecologia 2003, 137, 321-329. [CrossRef] [PubMed]

81. Hupet, F.; Vanclooster, M. Intraseasonal dynamics of soil moisture variability within a small agricultural maize cropped field. $J$. Hydrol. 2002, 261, 86-101. [CrossRef]

82. Querejeta, J.I.; Estrada-Medina, H.; Allen, M.F.; Jiménez-Osornio, J.J. Water source partitioning among trees growing on shallow karst soils in a seasonally dry tropical climate. Oecologia 2007, 152, 26-36. [CrossRef] 